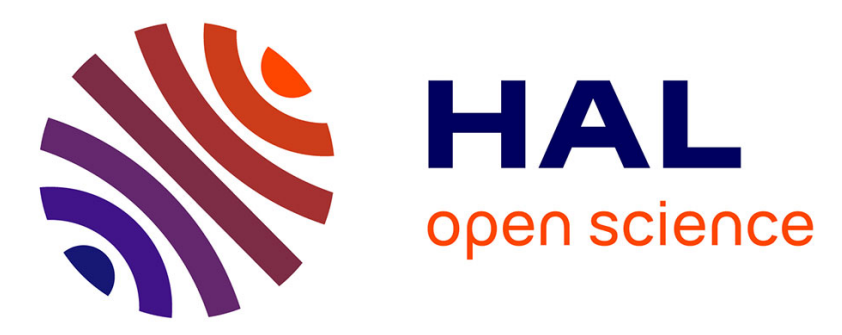

\title{
Intergenerational correlation of domestic work: Does gender matter?
}

Anne Solaz, François-Charles Wolff

\section{To cite this version:}

Anne Solaz, François-Charles Wolff. Intergenerational correlation of domestic work: Does gender matter?. 2013. halshs-00853391

\section{HAL Id: halshs-00853391 \\ https://shs.hal.science/halshs-00853391}

Preprint submitted on 22 Aug 2013

HAL is a multi-disciplinary open access archive for the deposit and dissemination of scientific research documents, whether they are published or not. The documents may come from teaching and research institutions in France or abroad, or from public or private research centers.
L'archive ouverte pluridisciplinaire HAL, est destinée au dépôt et à la diffusion de documents scientifiques de niveau recherche, publiés ou non, émanant des établissements d'enseignement et de recherche français ou étrangers, des laboratoires publics ou privés. 


\title{
Intergenerational correlation of domestic work: Does gender matter?"
}

\author{
Anne Solaz ${ }^{*}$
}

\author{
François-Charles Wolff*
}

July 2013

Résumé: En dépit de la plus grande fréquence de couples bi-actifs, les femmes continuent d'effectuer la plus grande part des tâches domestiques et parentales au sein du ménage. Dans cet article, nous nous interrogeons sur la persistance de cette inégalité de répartition du travail domestique entre les sexes en regardant le lien entre la quantité de travail domestique des parents et celles de leurs enfants co-résidents. A partir de l'enquête française sur les emplois du temps réalisée en 1999-2000 dans laquelle tous les membres de la famille âgés de plus de 14 ans ont été interrogés, les résultats des estimations mettent en évidence une corrélation positive entre le temps domestique que consacre l'enfant et celui que passent ses parents. Si la participation des filles aux tâches ménagères est beaucoup plus élevée que celle des garçons, l'effet d'une corrélation intergénérationnelle différenciée selon le sexe de l'enfant n'est pas systématiquement confirmé et dépend du type de tâches domestiques.

\begin{abstract}
Despite the increasing prevalence of dual-earner couples, women still perform the bulk of domestic and parental tasks within the household. In this paper, we investigate the role of the parental model in the persistence of this gender inequality. We study the possible correlation between the domestic time of parents and their young adult co-resident children using the French time-use survey conducted in 1999-2000 in which all family members aged above 14 years old were interviewed. Estimation results show a positive relationship between child and parental housework times. Girls' participation in domestic tasks is much higher than that of boys, but a gendered effect of the intergenerational relationship is not systematically confirmed and depends on the type of domestic tasks.
\end{abstract}

Keywords: domestic time, intergenerational transmission, gender roles

JEL Classification: J16, J22

\footnotetext{
\# We are indebted to two anonymous reviewers for their very helpful comments and suggestions on a previous draft of this paper. We also thank seminar participants at the Paris Seminar of Demographic Economy, the final workshop of the ANRGindhila project and the conference IATUR 2012. This article has benefited from the financial support of ANR-Gindhila.

*Corresponding author. INED, 133 bd Davout, 75020 Paris, France. E-mail: solaz@ined.fr

** LEMNA, Université de Nantes, BP 52231 Chemin de la Censive du Tertre, 44322 Nantes Cedex, France and INED, Paris, France. E-mail: francois.wolff@univ-nantes.fr http://www.sc-eco.univ-nantes.fr/ fcwolff
} 


\section{Introduction}

Although the gender gap in time spent on unpaid work has declined over the last decades, women still perform the bulk of domestic labor (Voicu et al., 2009, Shelton and John, 1996). The increasing number of dual-earner couples has led to a narrowing of this gender gap in housework, but has not eliminated it, even when both partners are working full-time. Trends in the male-female distribution of domestic activities in the United States (Bianchi et al., 2006) and France (Chenu and Herpin, 2002, Ricroch and Roumier, 2011) show almost the same pattern (see Figure 1). In both countries, the relative share of housework done by women has decreased since 1970 .

\section{Insert Figure 1 here}

A noticeable point is that this decrease is mainly due to a reduction of the time spent by women on unpaid work rather than an increase in male participation. In fact, the increase in female labor force participation has not been followed by a greater male involvement in domestic activities $(\text { Gershuny, 2000) })^{1}$. Time spent in housework by men (parental care being excluded) has remained more or less constant since the mid 1980s. Of course, the gender gap in domestic work is not of the same magnitude in all industrialized countries. As shown in Anxo et al. (2011), it is higher in Italy (roughly 22 hours a week) than in Sweden (around five hours), France being in an intermediate position ${ }^{2}$. Nonetheless, the gender gap remains apparent even in countries which have made substantial progress towards gender equality, such as Nordic countries.

What explains the persistence of the gender gap in domestic work? Why has the division of domestic labor been only modestly affected by the increase in female labor force participation? The aim of this article is to assess the role of the family in explaining gender differences in domestic tasks. Up to now, intergenerational transmission has been studied primarily to explain the persistence of income and educational inequalities (Lefranc, 2011) or labor force behavior (Fernandez et al., 2004). The correlation between the familial and labor force behaviors of children and of their parents goes beyond the social and economic situation of families. For instance, the intergenerational transmission of divorce (Amato and DeBoer, 2001, Wolfinger, 2000) and fertility (Booth and Kee, 2009) are key findings in the demographic literature.

Our contribution focuses on how a young adult's involvement in housework may be linked to domestic time devoted by parents. Several mechanisms may be evoked to explain an intergenerational correlation in domestic activities within the family. A first explanation is that the relationship might stem from imitation behaviors such as "doing by watching", parental behavior being a sort of model reproduced by children. It is also often claimed that during childhood, parents transmit common values and norms to their children that affect their preferences and encourage

\footnotetext{
${ }^{1}$ In Denmark, Bonke and Jensen (2012) observed an upturn in the trend for men from 1990.

2 The weekly gender gap in housework (childcare excluded) is around 13 hours in France.
} 
them to reproduce similar behaviors (see Becker, 1993). Another explanation could be related to a joint decision-making process within the family, the quantity or quality of household domestic goods being decided at the household level.

Whether the parent-child correlation is driven by some mechanism of transmission (related to norms or imitation) or by the household decision-making process, assessing the magnitude of intergenerational correlation in family behaviors is of great interest because it may explain the persistence of behaviors through subsequent generations with different external patterns. Housework is an interesting field for analyzing such intergenerational relationships because it lies at the heart of gender norms and might inform about the creation of these norms at young ages. More particularly, this paper also aims to test a possible gender asymmetry in the parent-child correlation in domestic tasks.

The first originality of our contribution is that the intergenerational correlation of unpaid work has rarely been studied so far, even though it has been advanced as an explanation for the transmission of working preferences. As emphasized in Fernandez et al. (2004, p. 1250), "men brought up by working mothers may have greater household productivity arising perhaps from a different attitude toward participating in housework". Determining whether domestic preferences are transmitted from one generation to the next within the family is hence a crucial issue. It means that individuals might begin married life with different skills inherited from the parenting model, and these skills might differ by sex.

This might affect the success of policies designed to promote gender equality. If the parentchild correlation in housework is very strong, then the external changing forces will remain weak, whereas if the intergenerational correlation is low, then public policy might have a much stronger effect. It might also help to target the appropriate population when implementing a policy. In order to reduce gender inequalities in the domestic workload, should governments help parents by developing childcare facilities or providing services to alleviate women's burden, or rather implement policies encouraging greater involvement of fathers?

Another originality of our research concerns our population of interest. We focus on the participation in domestic work of young adults who live with their parents, before couple formation and couple specialization, whereas most economic research on housework concentrates on primeage individuals after they have formed family unions, and often specifically on dual-earner couples (Alvarez and Miles, 2003, Hersch and Stratton, 1997) ${ }^{3}$. Our empirical analysis sheds new light on male and female comparative advantages before entering the marriage market.

\footnotetext{
${ }^{3}$ Exceptions are Bianchi and Robinson (1997) who focus on the time use of children and more recently Bonke (2010). The literature is more extensive in developing countries (for instance Vu, 2012, Lin and Adsera, 2012), where child labor (both paid and unpaid) is more frequent as an economic necessity and might compete with their education needs.
} 
The remainder of our paper is organized as follows. In the next Section, we provide a brief overview of the existing literature. In Section 3, we describe the French data and our various indicators of domestic time. We present our empirical strategy and discuss our econometric results in Section 4. Finally, Section 5 concludes.

\section{Literature review}

There is still a considerable debate about the factors contributing to the persistence and reproduction of gender inequality in the domestic workload. According the economics of the family, the unequal sharing of housework is the result of marriage specialization choices (Becker, 1973). Specialization implies that one spouse spends more time than the other in the domestic sphere.

This specialization is the result of an efficient division of work between husbands and wives and is thus one of the main benefits of marriage (Becker, 1973). Spouses investing proportionally more in domestic production are those who have a comparative advantage in this area. The advantage in home production might be the consequence of a relative disadvantage on the labor market (due to the gender wage gap) or might come from a productivity advantage in household activities ${ }^{4}$. These advantages in household work productivity may also be derived from early training (Lundberg and Rose, 1999) ${ }^{5}$. Curiously, little is known about this early training which seems to be at the heart of the gender inequality in housework division.

Up to now, the marriage specialization theory has failed to explain the following paradox. In couples where the wife earns more than her husband, the former still spends more time on domestic tasks. This stylized fact cannot be explained by pure economic factors. Gender norms and stereotypes have been advanced by the economic literature on identity formation to explain this over-investment of women in the domestic sphere (Akerlof and Kranton, 2000). There are gender norms about what a man or a woman should or should not do, and a social cost of deviating from the behaviors expected under these norms. These norms might partly explain the above paradox. As yet, economists know little about the creation and possible transmission of these norms within the family and how they maintain gender inequalities in domestic work from one generation to the next.

The focus on teenagers is very interesting because their behavior is not the result of a withinspouses negotiation process that aims to maximize efficiency by marital specialization. Even if their behavior were the result of family bargaining, there is no economic reason to think that this behavior might be gendered, except if gendered social norms exist. Teenagers who live with their parents are

\footnotetext{
${ }^{4}$ Equally, women's high levels of domestic responsibility may maintain gender inequalities in the labor market by limiting female labor force participation. For example, Hersch and Stratton (1997) show that unequal sharing of housework explains a large part of the gender wage gap (estimated between $27 \%$ and $38 \%$ ).

${ }^{5}$ Biological factors have also been suggested (specifically for child care activities), but other authors assume that there are no biological differences in the capacity to learn different domestic tasks (Baker and Jacobsen, 2007, Sofer and Thibout, 2011).
} 
generally not yet working and even if they are, the possible advantage for men on the labor market should be low at these ages.

However, a gender social norm might involve different behaviors if a boy (or a girl) grows up with some behavioral restrictions (either transmitted from parents, peers or the society) about what a boy or girl should do or should not do. According to Akerlof and Kranton's theory, if an individual deviates from the expected behavior of their sex, he/she will bear a disutility. We will analyze to what extent these norms and gender stereotypes may be transmitted directly by the parental model by measuring the correlation between the domestic behaviors of parents and their children.

The empirical literature on teenagers' participation in housework shows that even though their participation remains limited, girls participate significantly more than boys (Bonke, 2010, Bianchi and Robinson 1997, Kooreman 2007). Using the Spanish time-use survey, Alvarez and MilesTouya (2012) find that if parents adhere to traditional gender norms about housework division, the gap between the unpaid work performed by boys and girls is larger. Participation of boys in femaleoriented tasks, defined as those activities generally performed mainly by women (such as cooking, setting the table, washing dishes, doing laundry and cleaning the home), is particularly dependent on the father's investment in such tasks.

Using the American National Longitudinal Survey of Youth which includes information not only on children and parents, but also on the childhood of parents, Farré and Vella (2013) try to disentangle period/cohort and age effects in the transmission of values from parents to children to explain labor market participation across generations. They find a strong positive correlation between mothers' attitudes and daughters' labor market participation, also visible for daughters-inlaw, but they find no effect for sons ${ }^{6}$.

In what follows, we focus on the correlation of domestic production patterns between parents and children. Time devoted to housework is expected to vary substantially across families. This heterogeneity could be due to differences in demographic and economic individual characteristics, but also to different levels of preferences and requirements about, for instance, the cleanliness of the home, the expected quality of meals, or the type of activities with children. These preferences may be transmitted or imposed upon children who grow up in such an environment. For instance, messy parents are less likely to make their children tidy up their bedroom.

We will first look at the intergenerational correlation in domestic time (as a proxy of the quantity of household production) between parents and children. On the one hand, children might reduce their participation when parents devote a lot of time to domestic tasks due to substitution in family tasks. On the other hand, participation of both children and parents might be high because the

\footnotetext{
${ }^{6}$ The female employment rate responds by an estimated $14-19 \%$ to an increase of one standard deviation in an egalitarian values index.
} 
family applies high standards for the cleanliness of the home or the quality of meals. We also study how the parental model of time allocation and the associated stereotypes affect children's participation and examine whether intergenerational correlation differs when considering the role of fathers and mothers on boys and girls.

\section{Description of the data}

\subsection{The French Time Use survey}

In this paper, we study the intergenerational correlation of domestic time within the family using the Time Use survey conducted in France by INSEE from February 1998 to February 1999 on a sample of 8,186 respondents $^{7}$. Data was collected over a one-year period in order to account for possible seasonal variations in the way individuals organize their time. Three distinct questionnaires were used to collect information: i) a household questionnaire describing the composition of the household along with some characteristics of the dwelling and household resources; ii) an individual questionnaire with information on the respondent's work and leisure activities; iii) an individual daily booklet in which respondents were asked to note down the details of their activities over one randomly selected day. Each line corresponds to a time unit of exactly 10 minutes ${ }^{8}$.

The 1998-1999 survey is especially well-suited to study the pattern of intergenerational correlation in domestic work since all family members aged over 14 and living in the household had to complete both the individual questionnaire and the daily booklet. By linking the answers of the young adult co-resident children and those of their parents, we can observe the amount of time devoted to various domestic activities by family members of two different generations over the same period of time (all household members completed the booklet on the same day) ${ }^{9}$. A drawback of this focus on co-resident children is that it entails some sample selection which may potentially affect the measure of intergenerational correlation.

Indeed, the characteristics or preferences of older children still living with their parents are likely to differ from those of children living independently and this could affect their involvement in domestic activities. Several studies have shown that the leaving-home decision is positively related to the child's income (Le Blanc and Wolff, 2006) and is influenced by the educational choices of children, the receipt of public transfers as well as the comfort of the parental home (Ermisch and Di Salvo, 1997, Martinez-Granado and Ruiz-Castillo, 2002, Hu, 2001). All these characteristics should not

\footnotetext{
${ }^{7}$ The 1998-1999 Time Use survey is available online to researchers through the Quetelet network (http://www.reseauquetelet.cnrs.fr/spip/).

${ }^{8}$ Each respondent is required to note the start and end times of each activity, so there should be no measurement errors due to recall bias.

${ }^{9}$ In the last French Time Use survey conducted in 2009-2010, only one randomly selected member of the household aged above 10 and his/her spouse, if any, were interviewed. This precludes an investigation of the intergenerational correlation of time use and explains why we do not use the most recent time use dataset available in France.
} 
be orthogonal to their housework decision. For instance, co-resident children might be tempted to postpone their home-leaving decision if most domestic tasks are completed by their parents.

Unfortunately, there is no information in the Time survey on the number and characteristics of children living independently, and the direction of the selection bias is difficult to determine exante. On the one hand, if older co-resident children decide to stay longer at home because they contribute little to domestic tasks, this means that we would underestimate the parent-child correlation in such activities. On the other hand, parents may expect their older children to spend more time on domestic tasks as part as an implicit family contract. When considering the various reasons why young adults still live with their parents, the Eurobarometer shows that material constraints, mainly financial ones and the lack of affordable housing, are the most cited. At the same time, a comfortable life with parents without the responsibilities of independent living, which certainly include domestic work, is evoked by only 15\% of French young adults aged 15-30.

Overall, this suggests that the selection bias due to the restriction on co-resident children should be limited when studying the intergenerational correlation of domestic activities. Keeping this shortcoming in mind, we constructed a sample of co-resident children matched with their parents. This sample, in which each observation corresponds to one parent-child pair, includes 6,586 children of every age ${ }^{10}$. Since detailed information on time use of both the parents and their children is needed, we selected our sample in the following way.

Firstly, we excluded all the children below age 15 because in the French survey design respondents under 15 were not asked to fill in a daily booklet. Secondly, we excluded adult children aged above 23 , which corresponds approximately to the average age at leaving the parental home in France (23 years for daughters and slightly above 24 years for sons according to Eurostat, 2009) ${ }^{11}$. Our final sample contains 1,507 children aged $15-23$ belonging to 1,082 families. We now present the various indicators of domestic work considered in our empirical analysis.

As is usually the case in economic studies on domestic tasks, our first indicator is the total time spent by each family member on the different domestic tasks (expressed in minutes per day). This information is obtained directly from the daily booklet ${ }^{12}$. We classify the following activities as domestic: cooking, washing dishes, laying or clearing the table, activities linked to shopping for food and cleaning the home, laundry and ironing, paperwork, do-it-yourself and gardening, and caring for pets. We choose to exclude childcare because teenage participation in childcare is very dependent on the family composition (and the presence of siblings in the household who are young enough to

\footnotetext{
${ }^{10}$ The average age of the children is 13.3 years. Around one-half of them are below 13 years old.

${ }^{11}$ We have assessed the robustness of our results with respect to this upper age limit. We reach very similar conclusions with different values for the upper age.

${ }^{12}$ A few studies have used a measure of time spent on housework directly estimated by respondents. For a methodological discussion on housework indicators, see Blair and Lichter (1991).
} 
require childcare). Furthermore, child care, as a family-oriented activity, is also likely to increase the utility of caregivers (contrary to the other domestic activities).

A difficulty with the participation of teenagers in domestic tasks it that it may be less frequent and less regular than that of adults (Shelton and John, 1996). Thus, observing only one day may not necessarily be representative of the true contribution to the domestic workload. Nonetheless, the drawback of the daily interview is not specific to children as it also applies to working parents. Another frequent criticism of the total time indicator is that time differs from productivity. Some people may take very different amounts of time to perform a given task (for an output of the same quality). In the individual questionnaire of the Time Use survey, each person is asked whether he or she has undertaken one of the following activities over the last four weeks: shopping, cooking, cooking for guests, washing-up, cleaning, ironing, do-it-yourself, and gardening. Our second indicator therefore corresponds to the number of times the activity was performed over the last four weeks.

\subsection{The pattern of domestic tasks within the family}

Before turning to the importance of domestic tasks within the family, we begin with a description of our sample (see Table 1 ). It includes slightly more sons than daughters $(52.2 \%$ versus $47.8 \%)$. On average, the children are 18.3 years old and the mean number of children living in the parental home is 2.44 (whatever their age). The father's average age is around 47.7 years, 2.5 years more than the mother, and $27 \%$ of them have completed high school at least. The mother is more educated than the father in $25 \%$ of cases. The proportion of employed fathers is very high $(88.9 \%)$, while $36.9 \%$ of mothers have a full time job and $31.9 \%$ a part-time job. Finally, $29 \%$ of the respondents were interviewed on either a Saturday or a Sunday.

Insert Table 1

Table 2 gives some statistics summarizing the time devoted to domestic tasks by the children and their parents. The total time recorded in the booklet is positive for $61.4 \%$ of the children. This means that more than one-third do no housework on the day of interview, which seems a high proportion. For participants, the total contribution amounts to one and a half hours (92.6 minutes exactly). There are substantial differences when considering the different activities performed in the last month. On average, children are more likely to devote time to cleaning (54.1\%), shopping (50.0\%), washing-up (48\%) and cooking (42.3\%). The largest contributions for participants are observed for washing-up (15.2 times per month), cooking (10.8 times) and cleaning (9.2 times).

\section{Insert Table 2}

We observe significant differences in the behavior of boys and girls. The participation rate in domestic tasks is 21.9 percentage points higher for girls compared to boys (72.8\% versus $50.9 \%$ ). A 
similar pattern is found for the time devoted to domestic tasks among the subsample of participants. On average, boys devote 78.4 minutes to these activities, 25 minutes less than girls (92.6 minutes). So, our results suggest a gendered pattern of household work among young adult children living with their parents. Using the monthly frequency indicators, we also find that the participation rate is much higher for girls than for boys. The difference is large especially for cleaning $(+33.8 \%)$, ironing (+30.9\%), washing-up (+27.2\%) and cooking (+23.2\%). Conversely, boys are more frequently involved than girls in do-it-yourself $(+28.2 \%)$ and gardening $(+8.1 \%)^{13}$.

Comparing home behavior, we observe that parents are much more involved in domestic activities than their children. Their participation rate calculated from the daily booklet is $85.4 \%$, which is nearly $40 \%$ higher than that of the younger generation $(85.4 / 61.4=1.391)$. The gap is even higher when considering the time per participant. On average, fathers and mothers devote about 4 hours to domestic work compared to around 1.5 hours for children. For each selected activity, the participation rate is always higher for parents than for children: +31 percentage points for shopping, +29.7 points for gardening, and around 25-27 points for ironing, cooking and do-it-yourself.

As evidenced for the young generation, we find significant differences in the investment of fathers and mothers. While almost all mothers (98.2\%) have done some domestic tasks on the interview day, the proportion is 25.5 points lower for fathers. Among participants, the difference is quite remarkable since fathers spend more than two hours less on domestic activities than mothers (289.3 minutes for mothers versus 162.2 minutes for fathers). Do-it-yourself and gardening are characterized by higher male participation rates $(+53.9 \%$ for do-it-yourself, $+6.8 \%$ for gardening). Conversely, ironing $(+86.5 \%)$, cleaning $(+66.4 \%)$ and cooking $(+59.9 \%)$ are activities essentially performed by mothers. Among participants, there are also substantial differences by gender. Compared to mothers, the monthly frequency of fathers is 16.4 times lower per month for cooking, 13.3 times lower for cleaning and 12.3 times lower for washing-up.

A very interesting result from Table 2 is that the child's behavior tends to mirror the parental situation, albeit on a smaller scale. Tasks mainly performed by women at the parental level such as cooking, cleaning, washing-up and ironing are also those mainly performed by daughters among children. Conversely, the do-it yourself tasks mainly performed by fathers are also mainly performed by sons. Activities generally more evenly shared by male and female adults are also more often shared by male and female children.

Next, we investigate the correlations between the parents' and child's involvement in domestic activities, which are presented in Figure 2. When considering the total times recorded from

\footnotetext{
${ }^{13}$ When considering the monthly frequencies among participants, the largest negative gender gaps are observed for cooking (-3.6 times per month for boys), washing-up (-3.6) and cleaning $(-2.7)$. The gap is positive for do-it-yourself $(+2.8$ times per month for boys).
} 
the daily booklet, we obtain a positive correlation between the parents' and child's investments in domestic tasks. The coefficient of correlation is 0.160 and is significant at the $1 \%$ level. However, we note a few differences for the selected activities. The intergenerational correlation is large for shopping (0.144), washing-up (0.104), cleaning (0.142), do-it-yourself (0.118) and gardening (0.156), but it is not significant at the $5 \%$ level for the other activities ${ }^{14}$. If parents spend a lot of time on a task, it does seem to release children from doing the same task.

Insert Figure 2

This positive intergenerational correlation in domestic activities tends to rule out the idea that the efforts of the two generations could be substitutes within the household. It could mean that in some families there are more demanding standards for home cleanliness or expected quality of domestic production, for example. There appears to be a mimetic effect between children and parents.

In Figure 3, we investigate the role of gender in this process of intergenerational correlation by comparing the coefficients of correlation between sons and fathers, and between daughters and mothers ${ }^{15}$. Overall, the correlation in total domestic time is much higher for women than for men (0.179 versus 0.126$)$. The mother-daughter correlation is substantially higher for shopping, cleaning and, to a lesser extent, for ironing and gardening, while the reverse pattern is found for do-it-yourself and, more surprisingly, for washing-up and cooking. Albeit descriptive, these findings suggest that fathers could have an influential role on their children's participation in domestic activities. In what follows, we turn to an econometric analysis to assess the magnitude of the intergenerational correlation in domestic activities net of the influence of family characteristics.

Insert Figure 3

\section{Econometric analysis and results}

\subsection{Intergenerational correlation in domestic activities}

We first focus on the intergenerational correlation in housework time between the child and parent generations to check whether we observe a substitution or rather a mimetic effect between parental and child involvement in domestic tasks. For the presentation, we denote by $t_{k}$ the time devoted by a child $k$ to housework; $t_{f}$ and $t_{m}$ have a similar interpretation respectively for the father $f$ and for the mother $m$, so that $t_{p}=t_{f}+t_{m}$ is the total parental contribution to domestic tasks. We assess the correlation in housework time by estimating the following model:

$$
t_{k}=\beta_{p} t_{p}+\varepsilon_{k}
$$

\footnotetext{
${ }^{14}$ The correlation is even negative for cooking, with a coefficient of -0.005 (not significant)

${ }^{15}$ Standard errors reported in Table 3 are clustered at the family level.
} 
In (1), the coefficient $\beta_{p}$ sheds light on the correlation between child and parental housework time. We assume that the error term $\varepsilon_{k}$ is normally distributed such that $\varepsilon_{k} \sim \mathrm{N}\left(0, \sigma_{\varepsilon}^{2}\right)$. Since we have information on siblings for some families in our sample, we correct standard errors for clustering at the family level.

According to our data, many children perform no housework at all $(38.4 \%$ based on information reported in the daily booklet) ${ }^{16}$. This means that the dependent variable $t_{k}$ is censored. Assuming the existence of a latent variable $t_{k}^{*}$ measuring the propensity for a child to spend time on domestic tasks, we observe $t_{k}=0$ when $t_{k}^{*} \leq 0$ and $t_{k}=t_{k}^{*}$ otherwise, so that $t_{k}=\max \left(0 ; t_{k}^{*}\right)$. This censoring in the lower tail of the distribution is dealt with using a Tobit model. In subsection 4.3, we will investigate the sensitivity of our results to alternative specifications.

Estimates of specification (1) correspond to model A in Table 3. Overall, we obtain a positive correlation in the family times devoted to domestic activities, which is significant at the $1 \%$ level. At the sample means, each additional hour devoted by parents to housework increases by around 5.6 minutes $(0.093 * 60)$ the time devoted by the child to these activities. The marginal effect (computed separately) of the parental time on the expected value of the child's time is more than halved, at 2.3 minutes ${ }^{17}$.

At the monthly activity level, the coefficients of intergenerational correlation are all positive, although two of them are not statistically significant (cooking and ironing). The highest correlations are found for cooking for guests (if parents perform this task one additional time during the month, then the child's participation increases by 0.282 units), gardening $(+0.251)$, washing-up $(+0.201)$ and do-it-yourself $(+0.187)$. Some of these tasks are sometimes called semi-leisure (gardening and do-ityourself), or call for more skills (cooking for guests and washing up) and might require more training. Learning by doing from parents is possible. In any case, these results confirm the positive correlation between children and parental domestic participation that might come from a mimetic effect or learning process.

\section{Insert Table 3 here}

Because the intergenerational correlation in family times may be driven by background socioeconomic factors, we decide to introduce two sets of explanatory variables specific to the child and to the parents denoted by $X_{k}$ and $X_{p}$, with $\gamma_{p}$ and $\gamma_{k}$ the associate vectors of coefficients. We extend our previous model in the following way:

$$
t_{k}=X_{k} \gamma_{k}+X_{p} \gamma_{p}+\beta_{p} t_{p}+\varepsilon_{k}
$$

\footnotetext{
${ }^{16}$ As shown in Table 2, the proportion of zero values for participation in each activity per month ranges between $45.9 \%$ for cleaning to $88.7 \%$ for gardening (and even $92.7 \%$ for cooking for guests).

${ }^{17}$ There are different types of marginal effects in the Tobit model (see McDonald and Moffitt, 1980). While the estimated coefficients measure how the latent outcome changes with respect to changes in the explanatory variables, one can also estimate marginal effects of the truncated expected value or marginal effects of the censored expected value.
} 
We introduce the following covariates in our different regressions: age, number of siblings, number of sisters and child's birth order; father's age, difference between father and mother's age, blended family, father's education, two dummies comparing father and mother's education (mother and father have same education, mother is more educated), father's employment, mother's full-time employment, mother's part-time employment, household income (log), number of rooms per household member, presence of dishwasher and of microwave oven, having a garden, living in a rural area and interviewed on either Saturday or Sunday. Estimates of specification (2) correspond to model B in Table 3.

Our main finding is that controlling for family characteristics has almost no influence on the magnitude of the intergenerational correlation. This result means that the correlation observed was not due to some spurious relationship between observable characteristics of children and parents or of the household. It reveals the existence of an intergenerational correlation that goes beyond socioeconomic differences. On average, children with parents who spend more time on domestic activities are also likely to spend more time on domestic tasks.

It remains somewhat difficult to explain the children's contribution to domestic tasks. In particular, very few parental characteristics have a significant influence on the selected outcomes ${ }^{18}$. An exception is the influence of parental education since children with highly educated parents spend 25 minutes less on domestic tasks on average. If we assume that shopping, cooking or cleaning are necessary activities of daily life to be able to eat or live in a clean house, what will matter is not so much the parental socioeconomic situation, but whether the parents have themselves spent time on these domestic tasks or not. Clearly, the parental model plays a major role in the domestic participation of children.

Two important covariates in our regressions are child's gender and age. First, being a girl increases by more than one hour the total amount of time devoted to domestic tasks. The longer time spent by daughters compared to sons may be the sign of strong sex-oriented norms of domestic work within the family even at young ages. Secondly, time devoted to housework is positively correlated to age. On average, the total time spent increases by about 4 minutes for each additional year of age. Conversely, there is no interaction within the sibship since number of siblings, number of sisters and birth order do not affect the child's domestic activity. Finally, more time is devoted to domestic activities during the week-end, probably because young adults have more free time ${ }^{19}$.

After accounting for family background, cooking for guests, gardening, do-it-yourself, cleaning and shopping remain the activities characterized by the highest intergenerational

\footnotetext{
${ }^{18}$ Detailed estimates are available from the authors upon request.

${ }^{19}$ When the child is interviewed either on Saturday or Sunday, then the total amount of time spent on housework increases by 21 minutes.
} 
correlations. Depending on their gender, young adults tend to specialize in domestic activities. Girls spend more time than boys on ironing (+13.2 times per month), washing-up (+11.8 times per month), cleaning (+10.2 times per month) and cooking (+9.7 times per month). Conversely, they are less involved in do-it-yourself (-14.2 times per month) and, to a lesser extent, gardening (-4 times per month). Interestingly, these two last activities are not correlated with the child's age, whereas washing-up, cooking and ironing are the three activities most sensitive to the child's age. Parents might expect to receive help in those more routine activities as the children grow older.

We now investigate whether there is any difference in the parent-child transmission of housework for boys and girls. For that purpose, we define a dummy variable $\mathbb{S}$ such that $\mathbb{S}=1$ when the child is a girl and $\mathbb{S}=0$ otherwise. We estimate the following model:

$$
t_{k}=X_{k} \gamma_{k}+X_{p} \gamma_{p}+\beta_{p} t_{p}+\delta_{p}\left(t_{p} * \mathbb{s}\right)+\varepsilon_{k}
$$

where the dummy $\mathbb{S}$ is also included in the vector of control variables $X_{k}$. If the parental time spent on domestic tasks has a more pronounced influence either on sons or on daughters, then the coefficient $\delta_{p}$ associated with the crossed term $\left(t_{p} * \mathbb{S}\right)$ should be significant. It will be positive, for instance, if the intergenerational correlation in housework is higher for girls than for boys.

The corresponding estimates are presented in model $\mathrm{C}$ of Table 3 . When considering total domestic time, we find a comparable effect of the intergenerational coefficient but no difference of this coefficient between boys and girls. The positive estimate found for the interaction term is quite low and absolutely not significant at conventional level. Similar results are found for each activity, the only exception being cooking for guests with a positive interaction term (equal to 0.283 and significant at $10 \%$ ). So, we conclude that girls devote more time to domestic tasks than boys and that the child's effort and parental investment in domestic tasks are mutually influenced. Nonetheless, this intergenerational correlation is of similar magnitude for boys and girls.

\subsection{The distribution of parental housework time}

We now attempt to capture the specific influence of paternal involvement and maternal involvement, respectively, in domestic tasks. Indeed, a same amount of total parental time spent on domestic activities might be shared differently between the mother and father. A simple way to account for the contribution of both spouses consists in adding to equation (2) the two parental inputs $t_{f}$ and $t_{m}$ instead of the aggregate parental time $t_{p}$ :

$$
t_{k}=X_{k} \gamma_{k}+X_{p} \gamma_{p}+\beta_{f} t_{f}+\beta_{m} t_{m}+\varepsilon_{k}
$$

The question of interest is to know whether the role played by the father (measured by $\beta_{m}$ ) is different from that of the mother (measured by $\beta_{m}$ ). We implement a Wald test to assess the 
relevance of the null assumption $H_{0}: \beta_{f}=\beta_{m}$. The corresponding estimates are reported in model $\mathrm{A}$ of Table 4.

\section{Insert Table 4}

For the child's total domestic time, we find positive and significant coefficients for both paternal and maternal domestic time. Interestingly, the paternal influence is $73.5 \%$ higher than the maternal influence, but we are not able to reject the assumption that these two coefficients are similar (the significance level being around 30\%). In fact, we reach the same conclusion for the eight selected activities. The corresponding Wald statistic is never significant at conventional level. Thus, we conclude that for a given child the intergenerational correlation is not affected by who is involved in housework within the family.

An alternative specification to account for the relative role of spouses consists in adding an indicator measuring the share of the mother's contribution to the total spousal contribution. Let $t_{r}=t_{m} /\left(t_{f}+t_{m}\right)$. The corresponding model is:

$$
t_{k}=X_{k} \gamma_{k}+X_{p} \gamma_{p}+\beta_{p} t_{p}+\beta_{r} t_{r}+\varepsilon_{k}
$$

If there is no effect of the spousal distribution of domestic activities, then we should have $\beta_{r}=0$. However, the definition of $t_{r}$ poses a problem for families where neither parent performs any domestic activity. While this situation is uncommon for total domestic time (only nine households are concerned), it is much more frequent for specific activity frequencies like do-ityourself or gardening. In our regressions, we decide to exclude those families characterized by both $t_{f}=0$ and $t_{m}=0^{20}$. As shown in model B of Table 4, we reach very similar conclusions when estimating (5) compared to (4). While the child's effort is positively correlated with the total parental effort, it is not affected by the relative contribution of the mother, except for cleaning.

As they stand (with the exception of cleaning), our results suggest that the child's investment in housework does not depend on the specific contribution of each parent. However, in our specifications, we did not account for the fact that a large proportion of fathers never perform certain domestic tasks ${ }^{21}$. It could be that seeing the father involved in housework (even for a limited time) will influence the child's decision to undertake some domestic activities. Let $\mathbb{t}_{f}$ be a dummy variable such that $\mathbb{t}_{f}=1$ when $t_{f}>0$ and $\mathbb{t}_{f}=0$ otherwise. We estimate the following regression:

$$
t_{k}=X_{k} \gamma_{k}+X_{p} \gamma_{p}+\beta_{p} t_{p}+\beta_{f} \mathbb{t}_{f}+\varepsilon_{k}
$$

\footnotetext{
${ }^{20}$ In our sample, there are 308 children for whom neither parent had performed do-it-yourself activities over the last four weeks. This figure is even higher for gardening (549), because this activity requires some particular conditions (for instance, almost all those living in an apartment are excluded). We find very similar results by setting the missing maternal share to 0 and adding a dummy variable for observations characterized by $t_{f}=0$ and $t_{m}=0$.

${ }^{21}$ For total domestic time, $27.3 \%$ of fathers have null values. For the various activities, the proportion ranges between $25.2 \%$ for do-it-yourself and $93.6 \%$ for ironing.
} 
The corresponding estimates are in model $\mathrm{C}$ of Table 4. According to the French Time Use survey, a child devotes more time to domestic tasks when the father does some housework (net of the total parental contribution). When the father performs such activities, the domestic time spent by the child increases by around 17 minutes. Among the eight selected activities, the participation dummy is positive and significant for five of them at the $10 \%$ level. The highest effects are found for washing-up (+3.4 times per month), cleaning (+3.2 times per month) and do-it-yourself (+2.6 times per month). This highlights the symbolic role of paternal participation in domestic tasks in encouraging children to behave likewise (both in quantity and type of tasks). It appears less influential for the most equally shared tasks such as cooking, while it increases the likelihood of child involvement in the domestic tasks performed mainly by women, such as washing-up and cleaning, and also those mainly performed by men, such as gardening and do-it-yourself.

In a next step, we assess whether there is any difference in the respective influence of paternal and maternal inputs between boys and girls. In particular, it could be that the father's time is more influential for sons than for daughters while the maternal role is more important for daughters than for sons. To study this question, we add in equation (4) two interaction terms between the child's gender and, respectively, the paternal and maternal time:

$$
t_{k}=X_{k} \gamma_{k}+X_{p} \gamma_{p}+\beta_{f} t_{f}+\beta_{m} t_{m}+\delta_{f}\left(t_{f} * \mathbb{s}\right)+\delta_{m}\left(t_{m} * \mathbb{s}\right)+\varepsilon_{k}
$$

In (7), the coefficient $\delta_{f}$ indicates whether the influence of the father's time is the same for boys and for girls and $\delta_{m}$ has a similar interpretation for maternal time. Put differently, these coefficients are such that $\delta_{f}=\beta_{f}^{\mathrm{S}=1}-\beta_{f}^{\mathrm{S}=0}$ and $\delta_{m}=\beta_{m}^{\mathrm{S}=1}-\beta_{m}^{\mathrm{S}=0}$. We rely on a Wald test to test the assumption that $\delta_{f}-\delta_{m}=0$. Note that our approach corresponds to a difference-in-difference strategy since $\delta_{f}-\delta_{m}=\left(\beta_{f}^{s=1}-\beta_{f}^{s=0}\right)-\left(\beta_{m}^{s=1}-\beta_{m}^{s=0}\right)$. For the sake of robustness, we also extend our previous specification (5) by adding two interaction terms between the total parental time and the mother's relative contribution by the child's gender:

$$
t_{k}=X_{k} \gamma_{k}+X_{p} \gamma_{p}+\beta_{p} t_{p}+\beta_{r} t_{r}+\delta_{p}\left(t_{p} * \mathbb{s}\right)+\delta_{m}\left(t_{r} * \mathbb{s}\right)+\varepsilon_{k}
$$

We find very similar results with both sets of estimates, which are reported in Table 5 (models $A$ and $B)^{22}$. On the one hand, the child's total domestic time is not influenced by these new interaction terms. On the other hand, we observe interesting differences in the role of fathers and mothers, respectively, on sons and daughters for some activities. The coefficient $\delta_{f}$ is negative and significant for washing-up, ironing (at the 10\% level), do-it-yourself and gardening. For these activities, the father-son correlation is higher than the father-daughter correlation $\left(\beta_{f}^{\mathrm{s}=1}<\beta_{f}^{\mathrm{s}=0}\right)$

The higher correlation for male-oriented activities (mainly performed by men) was an expected result that may stem from both the social norm and the father's model. By contrast, our

\footnotetext{
${ }^{22}$ In panel B of Table 5, we drop observations with missing values for $t_{r}$, which occurs when both $t_{f}=0$ and $t_{m}=0$.
} 
result of a higher correlation for boys on almost all female-oriented tasks, which is significant for two of them, is more surprising and interesting. It suggests that the domestic behavior of sons is not only driven by social norms, but also by the father's participation (or by the joint decision process within household). A son's investment in such domestic tasks is more influenced by the father's involvement in such tasks than by that of the mother. Similarly, the coefficient of the mother $\delta_{m}$ is positive for cleaning and gardening. For these two activities, the mother's influence is stronger for daughters than for sons since $\beta_{m}^{\mathrm{s}=1}>\beta_{m}^{\mathrm{s}=0}$.

\section{Insert Table 5}

We compare the influence of fathers on sons and daughters to that of mothers by testing the assumption $\delta_{m}=\delta_{f}$. Results from a Wald test show that the maternal effect differs from the paternal effect on daughter's involvement (or boy's involvement) for four activities: washing-up, ironing, do-it-yourself and gardening. These results are confirmed by the specification with the share indicator (model B). For the cleaning activity, it seems that there is a mix of expectations about general cleanliness: the daughter's involvement increases both with the total time spent on cleaning activities and with the mother's relative contribution. Overall, our results suggest that a gendered intergenerational correlation of housework exists, but for some specific tasks only.

\subsection{Robustness checks}

In this subsection, we investigate more closely the robustness of our findings. In particular, we try alternative econometric specifications to estimate the intergenerational correlation in domestic activities and attempt to account for unobserved heterogeneity at the sibship level.

\section{Tobit model estimation}

Given the censoring of our various dependent variables, we turn to Tobit models to study the determinants of domestic tasks. A drawback of this parametric approach is that the consistency of the Tobit estimates depends crucially on the assumption of normality of the residual. We apply some diagnostic tests based on generalized residuals to test the null assumption of normality (see Cameron and Trivedi, 2005). Results from a Lagrange multiplier test lead to a strong rejection of the normality hypothesis ${ }^{23}$.

\footnotetext{
${ }^{23}$ Rewriting (2) as $t_{k}=X \beta+\varepsilon_{k}$ ( $X$ includes characteristics of both child and parents), we denote by $\hat{\beta}$ and $\hat{\sigma}_{\varepsilon}^{2}$ the estimated parameters. For uncensored observations, we calculate the four powers $E\left(\varepsilon_{k} \mid t_{k}>0\right), E\left(\varepsilon_{k}^{2} \mid t_{k}>0\right)$, $E\left(\varepsilon_{k}^{3} \mid t_{k}>0\right)$ and $E\left(\varepsilon_{k}^{4} \mid t_{k}>0\right)$ using $\hat{\varepsilon}_{k}=\left(t_{k}-X \hat{\beta}\right) / \hat{\sigma}_{\varepsilon}$. Let $\hat{z}=-X \hat{\beta} / \hat{\sigma}_{\varepsilon}$ and $\hat{\lambda}=\phi(-\hat{z}) /(1-\Phi(\hat{z}))$. For left-censored observations at zero, we calculate $E\left(\varepsilon_{k} \mid t_{k}=0\right)=-\hat{\lambda}, E\left(\varepsilon_{k}^{2} \mid t_{k}=0\right)=1-\hat{z} \hat{\lambda}, \quad E\left(\varepsilon_{k}^{3} \mid t_{k}=0\right)=-\left(2+\hat{z}^{2}\right) \hat{\lambda}$ and $E\left(\varepsilon_{k}^{4} \mid t_{k}=0\right)=3-\left(3 \hat{z}+\hat{z}^{3}\right) \hat{\lambda}$. The statistic for the Lagrange multiplier test is, for instance, equal to 78.5 for the child's daily domestic time. For the eight monthly activities, the statistic ranges between 25.4 (cooking) and 187.4 (shopping).
} 
It is thus important to assess whether the failure of normality affects our results. Specifically, we consider two alternative specifications. The first one is a simple two-part model, with one equation for the censoring mechanism (whether the participation in domestic time is null or not) and a second model for the outcome condition on strictly positive values ${ }^{24}$. The probability for a child of undertaking some domestic task is first estimated using a Probit model. The probability that the child takes part in domestic tasks during the day of interview is positively correlated with the total parental time $(t=4.23)$. Assuming that the two parts of the model are independent, the second part is estimated using an OLS regression on the subset of children involved in domestic tasks. We also get a positive correlation between the daily times of the parent and the child, with a coefficient of 0.056 $(t=4.08)$.

When considering each specific activity, we find that the parental activity has no effect on either the probability of participating or number of times per month for cooking and ironing. A similar pattern was found with the Tobit specification. The intergenerational correlation obtained from the Probit model is always positive and significant for the six remaining activities, while the correlation estimated on positive frequencies is positive and significant only for shopping, cleaning, do-it-yourself and gardening. We have also tried to estimate bivariate sample-selection models, but it is hard to find any relevant exclusion restrictions. Using a two-step estimation for the selection model, we note that the estimated correlation between the errors is not different from zero, showing no significant selection bias. Nonetheless, these results are based on a bivariate normality assumption which is itself questionable.

Since the validity of maximum likelihood methods for censored data requires a correct specification of the error distribution, several semiparametric alternatives have been proposed (see Chay and Powell, 2001). In what follows, we rely on the censored least absolute deviation (CLAD hereafter) estimator proposed by Powell (1984). The data are trimmed to compensate for the censoring issue and coefficients are obtained from a regression step applied to the trimmed sample $e^{25}$. When estimating (2) for the child's total daily time, the CLAD estimator gives a coefficient of 0.080 for the correlation with total parental time, with a bootstrapped standard error of 0.023 . This is very close to the value found with the Tobit specification, the parental time coefficient being equal to 0.094 . So, we are confident in the relevance of our results from the Tobit models, although the assumption of normality of errors for the various domestic tasks is not supported ${ }^{26}$.

\footnotetext{
${ }^{24}$ Results are available upon request.

${ }^{25}$ The key idea behind the CLAD estimator is that medians are preserved by monotone transformations of the data, which is the case for the least absolute deviations regression (Koenker and Bassett , 1978).

${ }^{26}$ We have also estimated a linear model to explain the child's domestic time. Again, we find a positive correlation between the child and parental daily time, with a coefficient equal to $0.060(t=5.40)$.
} 


\section{Joint estimation of parent-child behaviors}

So far, we have estimated several regressions which explain the time-use of the child as a function of the exogenous time-use of parents. However, the observed correlation between the parent and child's time values may simply be due to the household decision-making process ${ }^{27}$. Put differently, this means that a joint estimation of the parent's and child's decision to participate in domestic tasks could be more appropriate. We decide to turn to conditional mixed process estimators to jointly estimate the parental and child outcomes (see Roodman, 2011).

Consider first the case of the parent-child correlation. Instead of estimating (2), we now estimate a joint model with $t_{p}$ and $t_{k}$ as dependent variables. Let $t_{p}=X \gamma_{p}+\varepsilon_{p}$ and $t_{k}=X \gamma_{k}+\varepsilon_{k}$, with $X$ a set of family characteristics. Assuming that $t_{p}$ is continuous (almost all parents undertake domestic activities) and $t_{k}$ is censored, then the joint model comprises one continuous equation and one Tobit equation. The residuals $\varepsilon_{p}$ and $\varepsilon_{k}$ are supposed to follow a bivariate normal distribution. Denoting by $\rho$ the coefficient of correlation between $\varepsilon_{p}$ and $\varepsilon_{k}$, then this coefficient provides another measure of the correlation in domestic tasks between the parent and child behaviors net of family observed heterogeneity. ${ }^{28}$

Our results are shown in panel A of Table 6 . Concerning the daily domestic time, we find a value of 0.168 for the correlation between $\varepsilon_{p}$ and $\varepsilon_{k}$, which is significant at the 1 percent level. This coefficient obtained from a modeling of the joint parent-child participation is slightly higher than the intergenerational correlation of 0.094 reported in Table 3 . More broadly, we reach very similar conclusions with both approaches, i.e. an estimation of a joint parent-child model or an estimation of the child's time as a function of parental time. The coefficients of correlation between the parent and child residuals for the various activities over the last four weeks are always positive and significant, except for cooking and ironing.

Next, we try to disentangle the interaction between the child and, respectively, the father and the mother. As an alternative of (4), we estimate a joint model (again using a mixed process estimator) with $t_{f}, t_{m}$ and $t_{k}$ as dependent variables. The corresponding specification includes the three following equations $t_{f}=X \gamma_{f}+\varepsilon_{f}, t_{m}=X \gamma_{m}+\varepsilon_{m}$ and $t_{k}=X \gamma_{k}+\varepsilon_{k}$. The residuals $\varepsilon_{f}, \varepsilon_{m}$ and $\varepsilon_{k}$ are supposed to follow a trivariate normal distribution and we focus more closely on the three coefficients of correlation $\rho_{f m}, \rho_{f k}$ and $\rho_{m k}$ which shed light on the interaction between unobservables for the father-mother, father-child and mother-child relationships, respectively. The corresponding model is a trivariate Tobit when both $t_{f}, t_{m}$ and $t_{k}$ are treated as censored variables,

\footnotetext{
${ }^{27}$ Writing and estimating a structural model describing how parents and children decide about housework (bargaining powers and productivities would vary with age and sex of the child) is beyond the scope this paper.

${ }^{28}$ For some activities over the last four weeks, we estimate a parent-child model with two Tobit equations. We decide to use a Tobit model when the proportion of zeros for a dependent variable is greater than $5 \%$.
} 
while it comprises two Tobit equations and one continuous outcome when $t_{m}$ is treated as a continuous outcome $\left(t_{f} \text { and } t_{k} \text { are censored variables }\right)^{29}$.

Results are presented in panel B of Table 6. For daily domestic time, the three coefficients of correlation are positive, but we note that $\rho_{f c}>\rho_{m c}$. A similar result was found in Panel A of Table 4. There are a few differences for the selected activity frequencies over the last four weeks. Firstly, for activities like cooking, cleaning or ironing, the correlation between both parents is negative (but it is only significant for cooking), which suggests some substitution and specialization in the spousal contributions. Conversely, the spousal correlation is very high and positive for shared activities like cooking for guests, do-it-yourself or gardening. Secondly, the father-child correlations are always significant except for ironing (confirming the previous results of model $C$ in table 4 on father's participation), while the mother-child correlation is not significant for cooking, cleaning and ironing. Thirdly, we obtain similar father-child and mother-child coefficients for many activities like cooking for guests, washing up, do it yourself and gardening ${ }^{30}$.

\section{Unobserved heterogeneity and domestic tasks within the sibship}

An interesting feature of our data is that they provide information on the housework behavior of siblings. This allows us to deal with unobserved heterogeneity at the family level. Suppose, for instance, that there are some unobserved traits of the parents that are transmitted to the children, like preferences for leisure or altruism. Such unobservables might bias our previous estimates of the intergenerational correlation of housework. To investigate differences in behavior among siblings, we first estimate a model of the form:

$$
t_{p k}=X_{k} \gamma_{k}+X_{p} \gamma_{p}+\beta_{f} t_{f}+\beta_{m} t_{m}+\mu_{p}+\varepsilon_{p k}
$$

We explain the domestic time of a child $k$ with parents $p$ as a function of family characteristics $X_{k}$ (specific to each child), $X_{p}, t_{f}$ and $t_{m}$, and of two error terms $\mu_{p}$ and $\varepsilon_{p k}$. The term $\mu_{p}$ picks up the unobserved heterogeneity at the parental level, while $\varepsilon_{p k}$ is a random perturbation. We suppose that $\mu_{p}$ and $\varepsilon_{p k}$ are normally distributed such that $\mu_{p} \sim N\left(0 ; \sigma_{\mu}^{2}\right)$ and $\varepsilon_{p k} \sim N\left(0 ; \sigma_{\varepsilon}^{2}\right)$ and are independent of each other. Under the assumption that the family-specific error term is uncorrelated with the family characteristics, the corresponding model is a random effects Tobit model estimated by maximum likelihood and quadrature techniques.

As shown in column (1) of Table 7, we find little difference for total domestic time between the random effect specification and the simple Tobit regression ${ }^{31}$. We observe a positive influence of

\footnotetext{
${ }^{29}$ As shown in Table 6, the proportion of women not doing any domestic tasks over the last four weeks is very low for several activities.

${ }^{30}$ Conversely, the father-child coefficients tend to be higher for cooking and cleaning.

${ }^{31}$ We reach similar conclusions when estimating the random effect Tobit models for the eight selected activities.
} 
both the paternal and maternal domestic time on the child's time devoted to these tasks, but these two coefficients are not significantly different (the critical probability is 0.159 ). In column 2 , we introduce two interaction variables corresponding to the product of the child's gender and the domestic time of the father and mother. The random effect estimates do not support the idea that there are gender differences in the intergenerational transmission of housework behavior since both interaction terms remain insignificant.

Insert Table 7 here

A potential shortcoming of the random effect estimates is that they depend on the assumption that the family-specific component $\mu_{p}$ is independent of the family characteristics. There may be some reasons to believe that this assumption does not hold. For instance, more educated parents may have a higher (unobserved) preference for leisure. Thus, we decide to relax the assumption that the family component is orthogonal to the covariates and turn to a fixed effect specification. As a preliminary step, we focus on the extensive margin of housework and consider the probability $\operatorname{Pr}\left(t_{p k}>0\right)$ for a child $k$ of performing some domestic tasks on the day of interview. In our sample, $61.4 \%$ of children have positive time values ${ }^{32}$.

Specifically, we rely on the conditional Logit model originally proposed by Chamberlain (1980). A difficulty with this fixed effect specification is that all the characteristics remaining invariant at the household level are picked up by the family fixed effect. In our context, both the paternal and maternal time values do not vary among siblings by definition. This implies that our parameters of interest $\beta_{f}$ and $\beta_{m}$ (and also $\gamma_{p}$ ) are not identified. However, we can still consider a fixed effect framework to study the gender-specific impact of time spent by parents on housework by gender on the total time spent by their children. Indeed, the coefficients associated with the interaction terms $\left(t_{f} * \mathbb{s}\right)$ and $\left(t_{m} * \mathbb{s}\right)$ will be identified using information for families including siblings of different genders.

The fixed-effect Logit estimates are presented in column 3 of Table 7. All families with no variation in the domestic time values of siblings are dropped from the sample, which reduces the number of observations to 322 . This change in the sample composition is important as it is expected to affect our previous results. For instance, the average number of siblings is now much higher as families with only one child are excluded. We find that the probability of doing some housework on the day of interview is higher for girls than for boys. Also, while the paternal interaction term is insignificant, we obtain a negative coefficient for the maternal interaction term. This effect suggests that the intergenerational correlation in housework stemming from the maternal role is lower for girls than for boys, but it is only significant at the $10 \%$ level.

\footnotetext{
${ }^{32}$ Among families with two children living at home, in $19.9 \%$ of cases neither sibling performed any domestic tasks on the day of interview. The proportion of families with two positive time values is $40.6 \%$.
} 
Finally, we estimate a censored regression model with family fixed effect. A difficulty with the full estimation of fixed effect non-linear models is that parameters are subject to the incidental parameters problem ${ }^{33}$. While the bias in coefficients may be large with very small or small group sizes, it has been shown that there was almost no bias for the fixed effect estimates in the case of a Tobit model (Greene, 2004). We rely on the semiparametric trimmed least squares estimator proposed by Honoré (1992), which is consistent and asymptotically normal even when the time dimension of the panel is low. As shown in column (4), the conditional Logit and fixed effect Tobit estimates give very similar results since only the interaction term between maternal domestic time and the child's gender is significant.

\section{Concluding comments}

The aim of this paper was to study the intergenerational correlation of housework patterns and the possible asymmetrical gender effects. Our empirical analysis is based on the French time-use survey conducted in 1999-2000 in which all family members aged above 14 years old were interviewed. We thus link the housework decisions of teenagers and young adults to those of their parents. Our main results are as follows.

First, we find significant gender differences in the domestic work of young adults. Co-resident girls aged 15-23 spend around one hour more on housework than their male counterparts. This gender gap in unpaid work before couple formation is puzzling for economists since it cannot be linked to marital specialization, but is consistent with the theory of identity formation. Secondly, we obtain a positive intergenerational correlation in domestic work, meaning that domestic time spent by a child complements but does not substitute to time spent by parents. One additional hour of parental housework leads to an increase of around 5 minutes in the child's domestic participation. Thirdly, we observe a gender asymmetry in the intergenerational correlation of domestic tasks between boys and girls in certain domestic tasks.

The positive intergenerational correlation, which is robust to different specifications, may stem from various mechanisms. It may be due to parents who use more or less consciously gendered stereotypes when allocating household labor to children (Raley and Bianchi, 2006). It could also come from a joint decision-making process within the family, with household members sharing common values about housework. Lastly, it might be explained by the behavior of children who reproduce the parental model through mimetism or common preferences. Unfortunately, these explanations cannot be disentangled with the data at hand.

\footnotetext{
${ }^{33}$ Estimators of fixed effects are inconsistent in a panel of finite length (which is the case in our context given the average size of the sibship). The incidental parameters problem occurs when this inconsistency is transmitted to the estimator of the other parameters of the model.
} 
In this sense, our results may be helpful for targeting public policies towards greater gender equality. In particular, the magnitude of the intergenerational correlation of housework and gender roles should be taken into account when implementing public policies since they create persistent effects (for or against gender equality) over time. Since unequal participation of teenagers by gender is correlated to that of their parents, the current unequal gender division of parents will contribute to the unequal housework division of the next generation, who will themselves become parents one day and may potentially transmit these norms to a third generation. Appropriate policies integrating these long-term consequences are needed to avoid an intergenerational multiplier of gender inequality in housework. 


\section{References}

Akerlof G., Kranton R., (2000), "Economics and identity", Quarterly Journal of Economics, vol. 115, pp. 715-753.

Alvarez B., Miles D., (2003), "Gender effect on housework allocation: Evidence from Spanish twoearner couples", Journal of Population Economics, vol. 16, pp. 227-242.

Alvarez B., Miles-Touya D., (2012), "Exploring the relationship between parent's and children housework time in Spain", Review of Economic of the Household, vol. 10, pp. 299-318.

Amato P. R., DeBoer D.D., (2001), "The transmission of marital instability across generations: Relationship skills or commitment to marriage?", Journal of Marriage and Family, vol. 63, pp. 10381051.

Anxo D., Mencarini L., Pailhé A., Solaz A., Tanturri M-L., Flood L., (2010), "Gender differences in timeuse over the life-course. A comparative analysis of France, Italy, Sweden and the United States", Feminist Economics, vol. 17, pp. 159-195.

Baker M. J., Jacobsen J.P., (2007), "Marriage, specialization, and the gender division of labor", Journal of Labor Economics, vol. 25, pp. 763-793.

Becker G.S., (1973), "A theory of marriage : Part I", Journal of Political Economy, vol. 81, pp. 813-846.

Becker G.S., (1993), "Nobel Lecture: The economic way of looking at behavior", Journal of Political Economy, vol. 101, pp. 385-409.

Bianchi S.M., Robinson J., (1997), "What did you do today? Children's use of time, family composition, and the acquisition of social capital", Journal of Marriage and Family, vol. 59, pp. 33244.

Bianchi S.M., Robinson J., Milkie M.A., (2006), Changing Rhythms of American Family Life, ASA Rose Monographs, New York, Russell Sage.

Blair S.L., Lichter D.T., (1991), "Measuring the division of household labor: Gender segregation of housework among American couples", Journal of Family Issues, vol. 12, p. 91-113.

Bonke J., (2010), “Children's housework. Are girls more active than boys?", Electronic International Journal of Time Use Research, vol. 7, p. 1-16.

Bonke J., Jensen B., ( 2012), "Paid and unpaid work in Denmark. Towards gender equality", Electronic International Journal of Time Use Research, vol. 9, pp. 108-119.

Booth A., Kee H.J., (2009), "Intergenerational transmission of fertility patterns", Oxford Bulletin of Economics and Statistics, vol. 71, pp. 183-208.

Cameron A.C., Trivedi P.K., (2005), Microeconometrics. Methods and Applications, Cambridge University Press, New York.

Chamberlain G., (1980), "Analysis of covariance with qualitative data", Review of Economic Studies, vol. 47, pp. 225-238.

Chay K.Y., Powell J.L., (2001), "Semiparametric censored regression models", Journal of Economic Perspectives, vol. 15, pp. 29-42.

Chenu A., Herpin N., (2002), "Une pause dans la marche vers la civilisation des loisirs", Economie et statistique, $\mathrm{n}^{\circ} 352-353$, pp. 15-37.

Ermisch J., Di Salvo P., (1997), "The economic determinants of young people's household formation", Economica, vol. 64, pp. 627-644.

Eurostat, (2009), Youth in Europe. A Statistical Portrait, Eurostat Statistical Books. 
Farré L., Vella F., (2013), "The intergenerational transmission of gender roles attitudes and its implications for female labor force participation", Economica, vol. 80, pp. 219-247.

Fernández R., Fogli A., Olivetti C., (2004), "Mothers and sons: Preference formation and female labor force dynamics", Quarterly Journal of Economics, vol. 119, pp. 1249-1299.

Gershuny J., (2000), Changing Times Work and Leisure in Postindustrial Society, Oxford University Press, Oxford.

Greene W.H., (2004), "Fixed effects and bias due to the incidental parameters problem in the Tobit model", Econometric Reviews, vol. 23, pp. 125-147.

Hersch J., Stratton L. (1997), "Housework, fixed effects, and wages of married workers", Journal of Human Ressources, vol. 32, pp. 285-307.

Honoré B.E., (1992), "Trimmed lad and least squares estimation of truncated and censored regression models with fixed effects", Econometrica, vol. 60, pp. 533-565.

Hu W.-Y., (2001), "Welfare and family stability. Do benefits affect when children leave the nest?", Journal of Human Resources, vol. 36, pp. 274-303.

Koenker R., Bassett G., (1978), “Regression quantiles”, Econometrica, vol. 46, pp. 33-50.

Kooreman P., (2007), "Time, money, peers, and parents: Some data and theories on teenage behavior", Journal of Population Economics, vol. 20, pp. 9-33.

Le Blanc D., Wolff F.C., (2006), "Leaving home in Europe: The role of parent's and child's incomes", Review of Economics of the Household, vol. 4, pp. 53-73.

Lefranc A., (2011), "Educational expansion, earnings compression and changes in intergenerational economic mobility : Evidence from French cohorts, 1931-1976",mimeo, THEMA Working Paper 201111.

Lin, T-C., Adsera A., (2012), "Son preference and children's housework: The Case of India", IZA Discussion Paper, $\mathrm{n}^{\circ} 6929$.

Lundberg S., Rose E. (1999), "The determinants of specialization within marriage", mimeo, No UWEC2005-07.

Martinez-Granado M., Ruiz-Castillo J., (2002), "The decisions of Spanish youth: A cross-section study", Journal of Population Economics, vol. 15, pp. 305-330.

McDonald J. F., Moffitt R. A., (1980), "The use of Tobit analysis", Review of Economics and Statistics, vol. 62, pp. 318-321.

Powell J.L., (1984), "Least Absolute Deviations estimation for the censored regression model", Journal of Econometrics, vol. 25, n³, pp. 303-325.

Raley S., Bianchi S., (2006), "Sons, daughters, and family processes: Does gender of children matter?", Annual Review of Sociology, vol. 32, pp. 401-21.

Ricroch L., Roumier B., (2011), "Depuis 11 ans, moins de tâches ménagères, plus d'Internet", Insee Première, $\mathrm{n}^{\circ} 1377$.

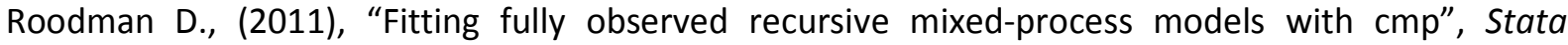
Journal, vol. 11, pp. 159-206.

Shelton B.A., John D., (1996), "The division of household labor", Annual Review of Sociology, vol. 22, pp. 299-322.

Sofer C., Thibout C., (2011), "Stereotypes upon abilities in domestic production and household behavior", mimeo, Document de Travail du Centre d'Economie de la Sorbonne 2011-75. 
Voicu M., Voicu B., Strapcova K., (2009), "Housework and gender inequality in European countries", European Sociological Review, vol. 25, pp. 365-377.

Vu T.M., (2012), "Are daughters always the losers in the chore war? Evidence using household and twin data from Vietnam", mimeo, OSIPP Discussion paper DP-2012-E-002.

Wolfinger N.H., (2000), "Beyond the intergenerational transmission of divorce: Do people replicate the patterns of marital instability they grew up with?", Journal of Family Issues, vol. 21, pp. 10611086. 
Figure 1. Trends in hours spent on primary housework activities per week

US, for married men and women

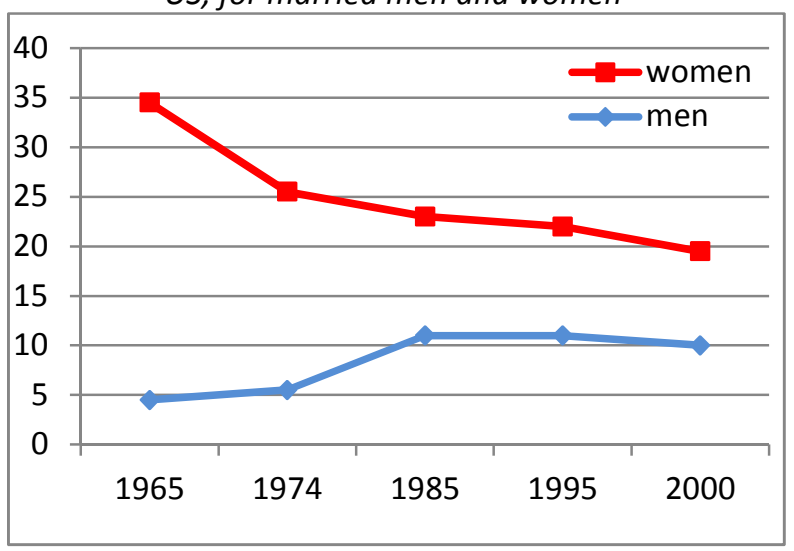

Data and figure from Bianchi et al. (2007).
France

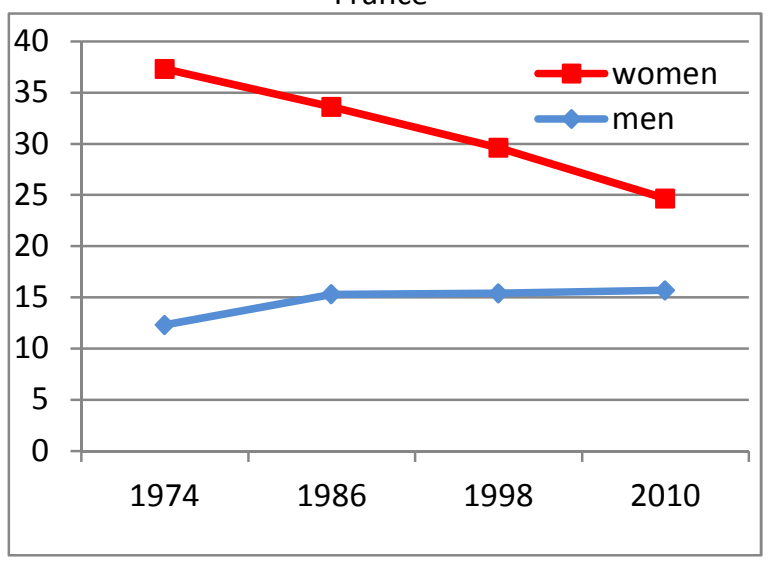

Data from Chenu and Herpin (2002) and Ricroch and Roumier (2011). 
Figure 2. Parent-child correlation in domestic activities

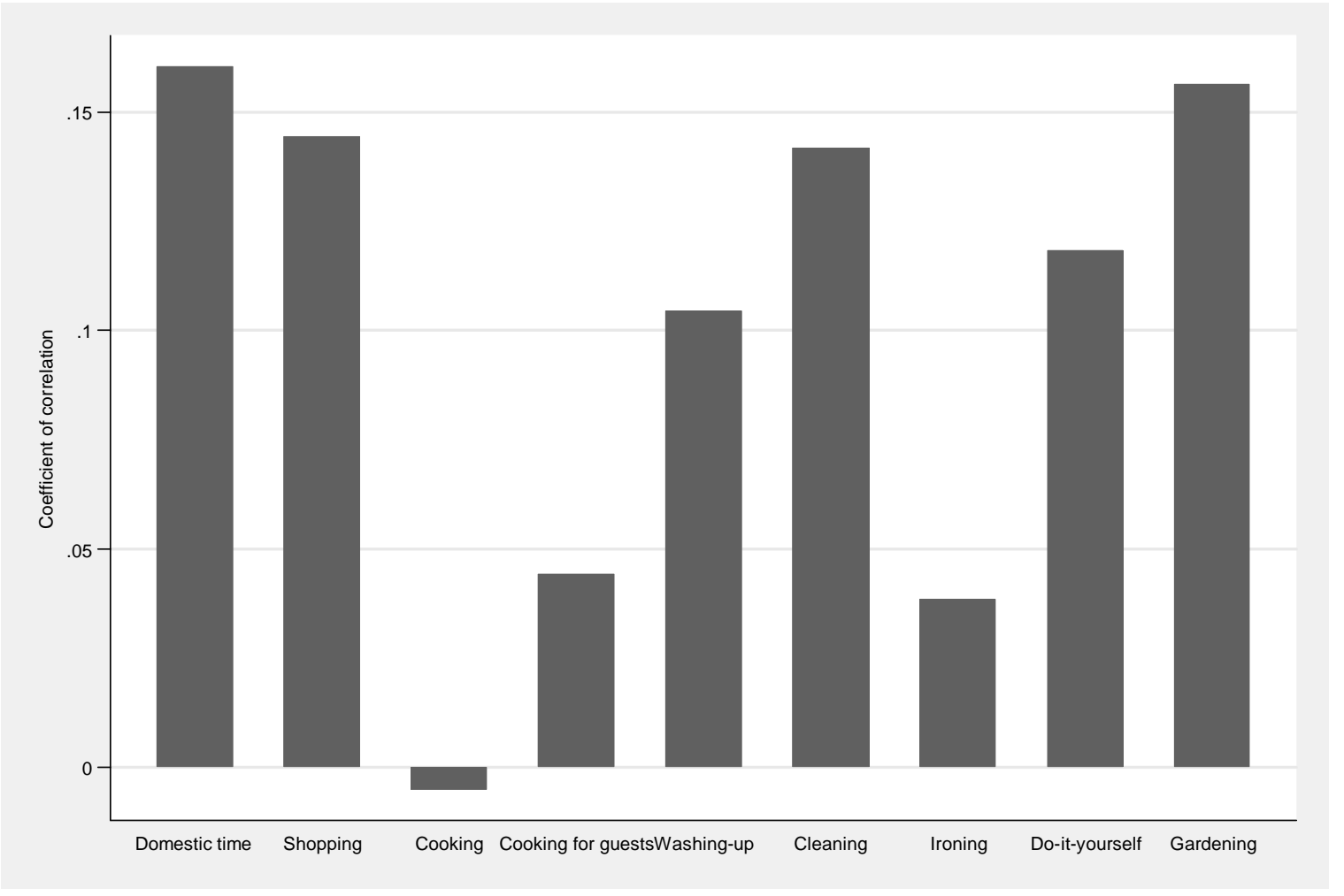

Source: INSEE Time Use survey 1999, authors' calculations. 
Figure 3. Father-son and mother-daughter correlation in domestic activities

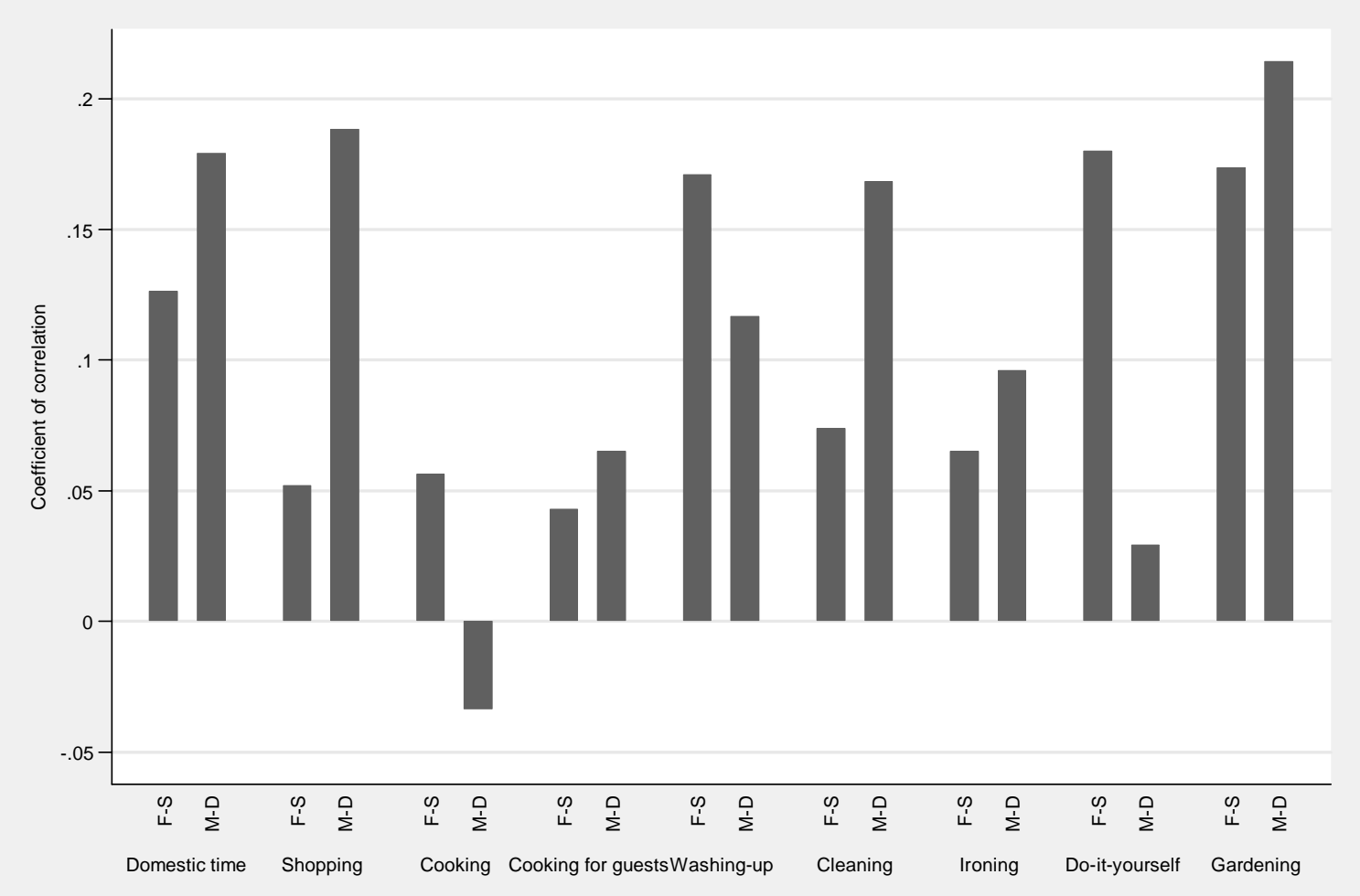

Source: INSEE Time Use survey 1999, authors' calculations.

Note: F-S stands for "father-son", M-D for "mother-daughter". 
Table 1. Descriptive statistics of the sample

\begin{tabular}{lllllll}
\hline Variables & Boys & \multicolumn{3}{l}{ Girls } & \multicolumn{2}{l}{ Boys and girls } \\
\cline { 2 - 6 } & mean & s.d. & mean & s.d. & mean & s.d. \\
\hline Child: girl & 0.000 & 0.000 & 1.000 & 0.000 & 0.478 & 0.500 \\
Child: age & 18.304 & 2.380 & 18.226 & 2.356 & 18.267 & 2.369 \\
Child: size of the sibship & 2.438 & 1.295 & 2.510 & 1.248 & 2.472 & 1.273 \\
Child: birth order & 1.450 & 0.727 & 1.480 & 0.764 & 1.464 & 0.745 \\
Father's age & 46.944 & 5.889 & 47.379 & 6.504 & 47.152 & 6.193 \\
Father's age - mother's age & 2.548 & 4.312 & 2.569 & 4.694 & 2.558 & 4.497 \\
Blended family & 0.079 & 0.270 & 0.108 & 0.311 & 0.093 & 0.290 \\
Father's education: no education, primary school & 0.291 & 0.455 & 0.315 & 0.465 & 0.303 & 0.460 \\
Father's education: secondary school & 0.440 & 0.497 & 0.404 & 0.491 & 0.423 & 0.494 \\
Father's education: high school, undergraduate & 0.162 & 0.368 & 0.168 & 0.374 & 0.165 & 0.371 \\
Father's education: graduate, postgraduate & 0.107 & 0.309 & 0.114 & 0.318 & 0.110 & 0.313 \\
Father's education > mother's education & 0.347 & 0.476 & 0.341 & 0.474 & 0.344 & 0.475 \\
Father's education = mother's education & 0.398 & 0.490 & 0.419 & 0.494 & 0.408 & 0.492 \\
Father's education < mother's education & 0.254 & 0.436 & 0.240 & 0.427 & 0.248 & 0.432 \\
Father's employment & 0.889 & 0.314 & 0.850 & 0.357 & 0.871 & 0.336 \\
Mother's full time employment & 0.369 & 0.483 & 0.319 & 0.466 & 0.345 & 0.476 \\
Mother's part time employment & 0.319 & 0.467 & 0.318 & 0.466 & 0.319 & 0.466 \\
Household income (log) & 9.687 & 0.485 & 9.651 & 0.513 & 9.670 & 0.499 \\
Number of rooms per household member & 1.185 & 0.387 & 1.168 & 0.385 & 1.177 & 0.386 \\
Dishwasher & 0.740 & 0.439 & 0.712 & 0.453 & 0.727 & 0.446 \\
Microwave oven & 0.635 & 0.482 & 0.632 & 0.482 & 0.634 & 0.482 \\
Garden & 0.762 & 0.426 & 0.738 & 0.440 & 0.750 & 0.433 \\
Rural area & 0.299 & 0.458 & 0.264 & 0.441 & 0.282 & 0.450 \\
Interviewed on Saturday/Sunday & 0.290 & 0.454 & 0.294 & 0.456 & 0.292 & 0.455 \\
\hline Number of observations & 786 & & 721 & & 1,507 &
\end{tabular}

Source: INSEE Time Use survey 1999, authors' calculations. 
Table 2. Parents' and child's investment in domestic tasks

\begin{tabular}{|c|c|c|c|c|c|c|c|c|c|}
\hline \multirow[t]{2}{*}{ Variables } & \multirow{2}{*}{$\begin{array}{l}\text { Daily } \\
\text { domestic } \\
\text { time }\end{array}$} & \multicolumn{8}{|c|}{ Number of activities performed over the last four weeks } \\
\hline & & Shopping & Cooking & $\begin{array}{l}\text { Cooking for } \\
\text { guests }\end{array}$ & Washing-up & Cleaning & Ironing & Do-it-yourself & Gardening \\
\hline Participation in domestic tasks & (over the day) & \multicolumn{8}{|c|}{ (over the last four weeks) } \\
\hline Fathers and mothers & 0.854 & 0.810 & 0.685 & 0.340 & 0.642 & 0.637 & 0.496 & 0.478 & 0.410 \\
\hline Father & 0.727 & 0.646 & 0.386 & 0.129 & 0.415 & 0.305 & 0.064 & 0.748 & 0.444 \\
\hline Mother & 0.982 & 0.974 & 0.985 & 0.551 & 0.868 & 0.969 & 0.928 & 0.209 & 0.376 \\
\hline$\Delta=$ Father-Mother & $-0.255^{* * *}$ & $-0.328 * * *$ & $-0.599 * * *$ & $-0.423 * * *$ & $-0.452 * * *$ & $-0.664 * * *$ & $-0.865 * * *$ & $0.539 * * *$ & $0.068 * * *$ \\
\hline Boys and girls & 0.614 & 0.500 & 0.423 & 0.073 & 0.480 & 0.541 & 0.224 & 0.224 & 0.113 \\
\hline Boys & 0.509 & 0.430 & 0.312 & 0.041 & 0.350 & 0.379 & 0.076 & 0.359 & 0.151 \\
\hline Girls & 0.728 & 0.577 & 0.544 & 0.108 & 0.623 & 0.717 & 0.386 & 0.076 & 0.071 \\
\hline$\Delta=$ Boys-Girls & $-0.219 * * *$ & $-0.147 * * *$ & $-0.232 * * *$ & $-0.067 * * *$ & $-0.273 * * *$ & $-0.338 * * *$ & $-0.309 * * *$ & $0.282^{* * *}$ & $0.081 * * *$ \\
\hline Time & (in minutes) & \multicolumn{8}{|c|}{ (in number of times over the last four weeks) } \\
\hline Fathers and mothers & 200.969 & 7.670 & 16.549 & 0.968 & 15.037 & 11.501 & 4.454 & 4.465 & 3.503 \\
\hline Fathers & 117.857 & 4.625 & 4.775 & 0.305 & 6.265 & 2.403 & 0.251 & 7.633 & 3.870 \\
\hline Mothers & 284.081 & 10.714 & 28.323 & 1.630 & 23.809 & 20.598 & 8.656 & 1.297 & 3.137 \\
\hline$\Delta=$ Fathers-Mothers & $-166.224 * * *$ & $-6.089 * *$ & $-23.547 * * *$ & $-1.325^{* *}$ & $-17.543 * * *$ & $-18.194 * * *$ & $-8.405 * * *$ & $6.336 * * *$ & $0.733^{* *}$ \\
\hline Boys and girls & 56.822 & 3.342 & 4.545 & 0.214 & 7.297 & 4.988 & 1.316 & 1.532 & 0.547 \\
\hline Boys & 39.911 & 2.611 & 2.659 & 0.087 & 4.534 & 2.842 & 0.323 & 2.620 & 0.653 \\
\hline Girls & 75.257 & 4.139 & 6.602 & 0.352 & 10.309 & 7.327 & 2.398 & 0.347 & 0.433 \\
\hline$\Delta=$ Boys-Girls & $-35.346 * * *$ & $-1.528^{* * *}$ & $-3.943 * * *$ & $-0.266 * * *$ & $-5.775 * * *$ & $-4.485^{* * *}$ & $-2.075^{* * *}$ & $2.273^{* * *}$ & 0.220 \\
\hline Time for participants & (in minutes) & \multicolumn{8}{|c|}{ (in number of times over the last four weeks) } \\
\hline Fathers and mothers & 235.231 & 9.468 & 24.154 & 2.846 & 23.434 & 18.032 & 8.979 & 9.333 & 8.559 \\
\hline Fathers & 162.201 & 7.166 & 12.386 & 2.371 & 15.083 & 7.874 & 3.948 & 10.206 & 8.734 \\
\hline Mothers & 289.264 & 10.999 & 28.761 & 2.957 & 27.431 & 21.223 & 9.324 & 6.206 & 8.352 \\
\hline$\Delta=$ Fathers-Mothers & $-127.063^{* * *}$ & $-3.833^{* *}$ & $-16.376^{* * *}$ & $-0.586 * *$ & $-12.348^{* * *}$ & $-13.349 * * *$ & $-5.376 * * *$ & $4.000 * * *$ & 0.383 \\
\hline Boys and girls & 92.573 & 6.679 & 10.754 & 2.927 & 15.189 & 9.223 & 5.867 & 6.852 & 4.853 \\
\hline Boy & 78.425 & 6.071 & 8.531 & 2.125 & 12.960 & 7.497 & 4.233 & 7.301 & 4.311 \\
\hline Girl & 103.352 & 7.173 & 12.143 & 3.256 & 16.555 & 10.219 & 6.219 & 4.545 & 6.118 \\
\hline$\Delta=$ Boy-Girl & $-24.927^{* * *}$ & $-1.102 *$ & $-3.612^{* * *}$ & -1.131 & $-3.595 * * *$ & $-2.722 * * *$ & $-1.986^{* *}$ & $2.756 * *$ & -1.807 \\
\hline
\end{tabular}

Source: INSEE Time Use survey 1999, authors' calculations.

Note: the sample co

at the family level. 
Table 3. Effect of parental domestic activity on child's domestic activity

\begin{tabular}{|c|c|c|c|c|c|c|c|c|c|}
\hline \multirow[t]{2}{*}{ Variables } & \multirow{2}{*}{$\begin{array}{l}\text { Daily } \\
\text { domestic } \\
\text { time }\end{array}$} & \multicolumn{8}{|c|}{ Number of activities performed over the last four weeks } \\
\hline & & Shopping & Cooking & $\begin{array}{l}\text { Cooking for } \\
\text { guests }\end{array}$ & Washing-up & Cleaning & Ironing & Do-it-yourself & Gardening \\
\hline \multicolumn{10}{|l|}{ Model A } \\
\hline $\begin{array}{l}\text { Parent: daily domestic time/activity over } \\
\text { the last four weeks }\end{array}$ & $\begin{array}{l}0.093^{* * *} \\
(5.80)\end{array}$ & $\begin{array}{l}0.121^{* * *} \\
(4.22)\end{array}$ & $\begin{array}{l}0.031 \\
(0.53)\end{array}$ & $\begin{array}{l}0.282^{* * *} \\
(2.71)\end{array}$ & $\begin{array}{l}0.201^{* * *} \\
(4.90)\end{array}$ & $\begin{array}{l}0.141^{* * *} \\
(4.63)\end{array}$ & $\begin{array}{l}0.018 \\
(0.32)\end{array}$ & $\begin{array}{l}0.187^{* * *} \\
(4.83)\end{array}$ & $\begin{array}{l}0.251^{* * *} \\
(5.14)\end{array}$ \\
\hline Other family characteristics & NO & NO & NO & NO & NO & NO & NO & NO & NO \\
\hline Log likelihood & -6171.9 & -3344.9 & -3203.4 & -633.6 & -3688.9 & -3761.3 & -1783.9 & -1805.5 & -964.6 \\
\hline \multicolumn{10}{|l|}{ Model B } \\
\hline Child: girl & $\begin{array}{l}64.952^{* * *} \\
(7.56)\end{array}$ & $\begin{array}{l}3.094 * * * \\
(3.79)\end{array}$ & $\begin{array}{l}9.745^{* * *} \\
(8.15)\end{array}$ & $\begin{array}{l}4.738^{* * *} \\
(3.09)\end{array}$ & $\begin{array}{l}11.800^{* * *} \\
(8.96)\end{array}$ & $\begin{array}{l}10.206 * * * \\
(10.12)\end{array}$ & $\begin{array}{l}13.248^{* * *} \\
(8.76)\end{array}$ & $\begin{array}{l}-14.236^{* * *} \\
(-9.06)\end{array}$ & $\begin{array}{l}-3.998 * * * \\
(-2.99)\end{array}$ \\
\hline Child: age & $\begin{array}{l}4.242^{* * *} \\
(2.71)\end{array}$ & $\begin{array}{l}0.343^{* *} \\
(2.30)\end{array}$ & $\begin{array}{l}1.339 * * * \\
(6.04)\end{array}$ & $\begin{array}{l}0.444^{* *} \\
(2.34)\end{array}$ & $\begin{array}{l}1.416^{* * *} \\
(5.35)\end{array}$ & $\begin{array}{l}0.387^{* *} \\
(2.08)\end{array}$ & $\begin{array}{l}0.774^{* * *} \\
(3.93)\end{array}$ & $\begin{array}{l}0.328 \\
(1.52)\end{array}$ & $\begin{array}{l}0.048 \\
(0.21)\end{array}$ \\
\hline $\begin{array}{l}\text { Parent: daily domestic time/activity over } \\
\text { the last four weeks }\end{array}$ & $\begin{array}{l}0.094^{* * *} \\
(5.77)\end{array}$ & $\begin{array}{l}0.111^{* * *} \\
(3.90)\end{array}$ & $\begin{array}{l}0.030 \\
(0.55)\end{array}$ & $\begin{array}{l}0.281^{* * *} \\
(3.12)\end{array}$ & $\begin{array}{l}0.196^{* * *} \\
(4.98)\end{array}$ & $\begin{array}{l}0.119^{* * *} \\
(3.97)\end{array}$ & $\begin{array}{l}0.071 \\
(1.19)\end{array}$ & $\begin{array}{l}0.161^{* * *} \\
(4.14)\end{array}$ & $\begin{array}{l}0.206^{* * *} \\
(4.43)\end{array}$ \\
\hline Other family characteristics & YES & YES & YES & YES & YES & YES & YES & YES & YES \\
\hline Log likelihood & -6098.4 & -3294.9 & -3091.1 & -602.9 & -3579.1 & -3645.2 & -1653.7 & -1692.8 & -929.0 \\
\hline \multicolumn{10}{|l|}{ Model C } \\
\hline Child: girl & $\begin{array}{l}52.306^{* * *} \\
(3.56)\end{array}$ & $\begin{array}{l}1.828^{*} \\
(1.74)\end{array}$ & $\begin{array}{l}11.596 * * * \\
(3.18)\end{array}$ & $\begin{array}{l}3.975^{* *} \\
(2.58)\end{array}$ & $\begin{array}{l}13.970^{* * *} \\
(5.24)\end{array}$ & $\begin{array}{l}8.087^{* * *} \\
(5.15)\end{array}$ & $\begin{array}{l}13.029 * * * \\
(7.37)\end{array}$ & $\begin{array}{l}-12.640 * * * \\
(-6.96)\end{array}$ & $\begin{array}{l}-4.620^{* * *} \\
(-2.70)\end{array}$ \\
\hline Child: age & $\begin{array}{l}4.237^{* * *} \\
(2.71)\end{array}$ & $\begin{array}{l}0.338^{* *} \\
(2.27)\end{array}$ & $\begin{array}{l}1.340^{* * *} \\
(6.04)\end{array}$ & $\begin{array}{l}0.456^{* *} \\
(2.40)\end{array}$ & $\begin{array}{l}1.410^{* * *} \\
(5.32)\end{array}$ & $\begin{array}{l}0.388^{* *} \\
(2.09)\end{array}$ & $\begin{array}{l}0.772^{* * *} \\
(3.94)\end{array}$ & $\begin{array}{l}0.341 \\
(1.58)\end{array}$ & $\begin{array}{l}0.053 \\
(0.23)\end{array}$ \\
\hline $\begin{array}{l}\text { Parent: daily domestic time/activity over } \\
\text { the last four weeks }\end{array}$ & $\begin{array}{l}0.078^{* * *} \\
(3.76)\end{array}$ & $\begin{array}{l}0.068 \\
(1.57)\end{array}$ & $\begin{array}{l}0.060 \\
(0.74)\end{array}$ & $\begin{array}{l}0.152 \\
(1.41)\end{array}$ & $\begin{array}{l}0.234^{* * *} \\
(4.13)\end{array}$ & $\begin{array}{l}0.071^{*} \\
(1.70)\end{array}$ & $\begin{array}{l}0.057 \\
(0.61)\end{array}$ & $\begin{array}{l}0.211^{* * *} \\
(4.27)\end{array}$ & $\begin{array}{l}0.184^{* * *} \\
(3.71)\end{array}$ \\
\hline $\begin{array}{r}\text { Parent: daily domestic time/activity over } \\
\text { the last four weeks * Child : girl }\end{array}$ & $\begin{array}{l}0.031 \\
(1.03)\end{array}$ & $\begin{array}{l}0.080 \\
(1.50)\end{array}$ & $\begin{array}{l}-0.056 \\
(-0.53)\end{array}$ & $\begin{array}{l}0.283^{*} \\
(1.87)\end{array}$ & $\begin{array}{l}-0.071 \\
(-0.99)\end{array}$ & $\begin{array}{l}0.090 \\
(1.61)\end{array}$ & $\begin{array}{l}0.023 \\
(0.20)\end{array}$ & $\begin{array}{l}-0.145 \\
(-1.59)\end{array}$ & $\begin{array}{l}0.055 \\
(0.64)\end{array}$ \\
\hline Other family characteristics & YES & YES & YES & YES & YES & YES & YES & YES & YES \\
\hline Log likelihood & -6097.8 & -3293.5 & -3090.1 & -601.8 & -3578.6 & -3644.0 & -1653.6 & -1691.1 & -928.7 \\
\hline
\end{tabular}

Source: INSEE Time Use survey 1999, authors' calculations.

Note: estimates from Tobit models. Standard errors are clustered at the family level, significance levels being respectively $1 \%(* * *), 5 \%\left({ }^{* *}\right)$ and $10 \%(*)$. The sample comprises 1,507 children (1,082 families). The other family characteristics include number of siblings, number of sisters, birth order, father's age, difference between father and mother's age, blended family, father's education (four categories), two dummies comparing father and mother's education (mother and father have same education, mother is more educated), father's employment, mother's fulltime employment, mother's part-time employment, household income (log), number of rooms per household member, presence of dishwasher and of microwave oven, having a garden, living in a rural area and interviewed on either Saturday or Sunday. 
Table 4. Effect of paternal and maternal domestic activity on child's domestic activity

\begin{tabular}{|c|c|c|c|c|c|c|c|c|c|}
\hline \multirow[t]{2}{*}{ Variables } & \multirow{2}{*}{$\begin{array}{l}\text { Daily } \\
\text { domestic } \\
\text { time }\end{array}$} & \multicolumn{8}{|c|}{ Number of activities performed over the last four weeks } \\
\hline & & Shopping & Cooking & $\begin{array}{l}\text { Cooking for } \\
\text { guests }\end{array}$ & Washing-up & Cleaning & Ironing & Do-it-yourself & Gardening \\
\hline \multicolumn{10}{|l|}{ Model A } \\
\hline Child: girl & $\begin{array}{l}65.011 * * * \\
(7.57)\end{array}$ & $\begin{array}{l}3.136^{* * *} \\
(3.84)\end{array}$ & $\begin{array}{l}9.750 * * * \\
(8.16)\end{array}$ & $\begin{array}{l}4.795^{* * *} \\
(3.13)\end{array}$ & $\begin{array}{l}11.801 * * * \\
(8.96)\end{array}$ & $\begin{array}{l}10.246^{* * *} \\
(10.16)\end{array}$ & $\begin{array}{l}13.302^{* * *} \\
(8.77)\end{array}$ & $\begin{array}{l}-14.262^{* * *} \\
(-9.09)\end{array}$ & $\begin{array}{l}-3.993 * * * \\
(-2.97)\end{array}$ \\
\hline Child: age & $\begin{array}{l}4.265^{* * *} \\
(2.73)\end{array}$ & $\begin{array}{l}0.343^{* *} \\
(2.30)\end{array}$ & $\begin{array}{l}1.338^{* * *} \\
(6.04)\end{array}$ & $\begin{array}{l}0.448^{* *} \\
(2.36)\end{array}$ & $\begin{array}{l}1.416^{* * *} \\
(5.35)\end{array}$ & $\begin{array}{l}0.384^{* *} \\
(2.07)\end{array}$ & $\begin{array}{l}0.780^{* * *} \\
(3.95)\end{array}$ & $\begin{array}{l}0.325 \\
(1.50)\end{array}$ & $\begin{array}{l}0.048 \\
(0.21)\end{array}$ \\
\hline $\begin{array}{l}\text { Father: daily domestic time/activity over } \\
\text { the last four weeks }\end{array}$ & $\begin{array}{l}0.118^{* * *} \\
(4.01)\end{array}$ & $\begin{array}{l}0.075 \\
(1.52)\end{array}$ & $\begin{array}{l}0.048 \\
(0.86)\end{array}$ & $\begin{array}{l}0.477^{* *} \\
(2.21)\end{array}$ & $\begin{array}{l}0.188^{* * *} \\
(3.42)\end{array}$ & $\begin{array}{l}0.214^{* * *} \\
(3.30)\end{array}$ & $\begin{array}{l}0.385 \\
(1.37)\end{array}$ & $\begin{array}{l}0.146^{* * *} \\
(3.05)\end{array}$ & $\begin{array}{l}0.209 * * * \\
(3.44)\end{array}$ \\
\hline $\begin{array}{l}\text { Mother: daily domestic time/activity over } \\
\text { the last four weeks }\end{array}$ & $\begin{array}{l}0.068^{* *} \\
(2.34)\end{array}$ & $\begin{array}{l}0.132^{* * *} \\
(3.60)\end{array}$ & $\begin{array}{l}-0.029 \\
(-0.35)\end{array}$ & $\begin{array}{l}0.234^{* *} \\
(2.30)\end{array}$ & $\begin{array}{l}0.203^{* * *} \\
(3.64)\end{array}$ & $\begin{array}{l}0.086^{* *} \\
(2.37)\end{array}$ & $\begin{array}{l}0.060 \\
(0.99)\end{array}$ & $\begin{array}{l}0.212^{* *} \\
(2.44)\end{array}$ & $\begin{array}{l}0.203^{* *} \\
(2.40)\end{array}$ \\
\hline Test: Father's time = mother's time [value;prob] & {$[1.07 ; 0.302]$} & {$[0.79 ; 0.374]$} & {$[0.90 ; 0.343]$} & {$[1.00 ; 0.318]$} & {$[0.04 ; 0.848]$} & {$[2.64 ; 0.104]$} & {$[1.28 ; 0.259]$} & {$[0.39 ; 0.533]$} & {$[0.01 ; 0.926]$} \\
\hline Log likelihood & -6097.4 & -3294.4 & -3090.8 & -602.5 & -3579.1 & -3643.4 & -1653.1 & -1692.5 & -928.9 \\
\hline \multicolumn{10}{|l|}{ Model B } \\
\hline Child: girl & $\begin{array}{l}63.334^{* * *} \\
(7.39)\end{array}$ & $\begin{array}{l}3.105^{* * *} \\
(3.81)\end{array}$ & $\begin{array}{l}9.774^{* * *} \\
(8.17)\end{array}$ & $\begin{array}{l}6.343^{* * *} \\
(2.98)\end{array}$ & $\begin{array}{l}11.916^{* * *} \\
(8.74)\end{array}$ & $\begin{array}{l}10.139 * * * \\
(10.06)\end{array}$ & $\begin{array}{l}13.204^{* * *} \\
(8.35)\end{array}$ & $\begin{array}{l}-14.401 * * * \\
(-8.67)\end{array}$ & $\begin{array}{l}-4.448 * * * \\
(-3.04)\end{array}$ \\
\hline Child: age & $\begin{array}{l}4.239 * * * \\
(2.71)\end{array}$ & $\begin{array}{l}0.346^{* *} \\
(2.32)\end{array}$ & $\begin{array}{l}1.334^{* * *} \\
(6.02)\end{array}$ & $\begin{array}{l}0.445^{*} \\
(1.85)\end{array}$ & $\begin{array}{l}1.277^{* * *} \\
(4.75)\end{array}$ & $\begin{array}{l}0.386^{* *} \\
(2.06)\end{array}$ & $\begin{array}{l}0.772^{* * *} \\
(3.70)\end{array}$ & $\begin{array}{l}0.253 \\
(1.10)\end{array}$ & $\begin{array}{l}-0.234 \\
(-0.98)\end{array}$ \\
\hline $\begin{array}{l}\text { Parents: daily domestic time/activity over } \\
\text { the last four weeks }\end{array}$ & $\begin{array}{l}0.085^{* * *} \\
(4.91)\end{array}$ & $\begin{array}{l}0.108^{* * *} \\
(3.70)\end{array}$ & $\begin{array}{l}-0.010 \\
(-0.16)\end{array}$ & $\begin{array}{l}0.204^{* *} \\
(2.27)\end{array}$ & $\begin{array}{l}0.150^{* * *} \\
(2.96)\end{array}$ & $\begin{array}{l}0.112^{* * *} \\
(3.72)\end{array}$ & $\begin{array}{l}0.075 \\
(1.17)\end{array}$ & $\begin{array}{l}0.130^{* * *} \\
(3.10)\end{array}$ & $\begin{array}{l}0.159^{* * *} \\
(3.35)\end{array}$ \\
\hline $\begin{array}{c}\text { Share of mother's daily domestic time/activity } \\
\text { over the last four weeks }\end{array}$ & $\begin{array}{l}-17.983 \\
(-1.03)\end{array}$ & $\begin{array}{l}-1.054 \\
(-0.76)\end{array}$ & $\begin{array}{l}-2.266 \\
(-0.89)\end{array}$ & $\begin{array}{l}-0.426 \\
(-0.23)\end{array}$ & $\begin{array}{l}-0.925 \\
(-0.37)\end{array}$ & $\begin{array}{l}-5.757^{* * *} \\
(-2.80)\end{array}$ & $\begin{array}{l}0.175 \\
(0.06)\end{array}$ & $\begin{array}{l}0.943 \\
(0.54)\end{array}$ & $\begin{array}{l}0.668 \\
(0.45)\end{array}$ \\
\hline $\begin{array}{l}\text { Log likelihood } \\
\text { Model C }\end{array}$ & -6074.5 & -3294.5 & -3091.3 & 601.9 & -3579.0 & -3641.2 & -1653.7 & -1692.3 & -928.1 \\
\hline Child: girl & $\begin{array}{l}64.865^{* * *} \\
(7.55)\end{array}$ & $\begin{array}{l}3.114 * * * \\
(3.80)\end{array}$ & $\begin{array}{l}9.841 * * * \\
(8.20)\end{array}$ & $\begin{array}{l}4.793^{* * *} \\
(3.12)\end{array}$ & $\begin{array}{l}11.868^{* * *} \\
(9.07)\end{array}$ & $\begin{array}{l}10.349 * * * \\
(10.23)\end{array}$ & $\begin{array}{l}13.288^{* * *} \\
(8.78)\end{array}$ & $\begin{array}{l}-14.274 * * * \\
(-9.08)\end{array}$ & $\begin{array}{l}-3.831^{* * *} \\
(-2.86)\end{array}$ \\
\hline Child: age & $\begin{array}{l}4.476^{* * *} \\
(2.86)\end{array}$ & $\begin{array}{l}0.357^{* *} \\
(2.40)\end{array}$ & $\begin{array}{l}1.354^{* * *} \\
(6.11)\end{array}$ & $\begin{array}{l}0.453^{* *} \\
(2.38)\end{array}$ & $\begin{array}{l}1.452^{* * *} \\
(5.46)\end{array}$ & $\begin{array}{l}0.417^{* *} \\
(2.25)\end{array}$ & $\begin{array}{l}0.775^{* * *} \\
(3.93)\end{array}$ & $\begin{array}{l}0.355 \\
(1.65)\end{array}$ & $\begin{array}{l}0.062 \\
(0.28)\end{array}$ \\
\hline Parents: domestic time/activity & $\begin{array}{l}0.081^{* * *} \\
(4.72)\end{array}$ & $\begin{array}{l}0.097^{* * *} \\
(3.27)\end{array}$ & $\begin{array}{l}-0.024 \\
(-0.38)\end{array}$ & $\begin{array}{l}0.251^{* * *} \\
(2.71)\end{array}$ & $\begin{array}{l}0.139 * * * \\
(3.10)\end{array}$ & $\begin{array}{l}0.093^{* * *} \\
(3.06)\end{array}$ & $\begin{array}{l}0.067 \\
(1.13)\end{array}$ & $\begin{array}{l}0.128^{* * *} \\
(3.02)\end{array}$ & $\begin{array}{l}0.174^{* * *} \\
(3.17)\end{array}$ \\
\hline Father: participation in domestic time/activity & $\begin{array}{l}16.792^{* *} \\
(2.03)\end{array}$ & $\begin{array}{l}1.247^{*} \\
(1.74)\end{array}$ & $\begin{array}{l}1.920 \\
(1.60)\end{array}$ & $\begin{array}{l}1.069 \\
(1.06)\end{array}$ & $\begin{array}{l}3.367^{* *} \\
(2.49)\end{array}$ & $\begin{array}{l}3.155^{* * *} \\
(3.59)\end{array}$ & $\begin{array}{l}1.243 \\
(0.76)\end{array}$ & $\begin{array}{l}2.637^{* *} \\
(2.08)\end{array}$ & $\begin{array}{l}2.245^{*} \\
(1.66)\end{array}$ \\
\hline Log likelihood & -6096.1 & -3293.3 & -3089.9 & -602.5 & -3575.7 & -3637.9 & -1653.5 & -1690.5 & -927.2 \\
\hline
\end{tabular}

Source: INSEE Time Use survey 1999, authors' calculations.

Note: estimates from Tobit models. Standard errors are clustered at the family level, significance levels being respectively $1 \%\left({ }^{* * *}\right), 5 \%(* *)$ and $10 \%(*)$. The sample comprises 1,507 children

( 1,082 families). The other family characteristics include number of siblings, number of sisters, birth order, father's age, difference between father and mother's age, blended family, father's education (four categories), two dummies comparing father and mother's education (mother and father have same education, mother is more educated), father's employment, mother's fulltime employment, mother's part-time employment, household income (log), number of rooms per household member, presence of dishwasher and of microwave oven, having a garden, living in a rural area and interviewed on either Saturday or Sunday. 
Table 5. Effect of paternal and maternal domestic activity on child's domestic activity, by gender

\begin{tabular}{|c|c|c|c|c|c|c|c|c|c|}
\hline \multirow[t]{2}{*}{ Variables } & \multirow{2}{*}{$\begin{array}{l}\text { Daily } \\
\text { domestic } \\
\text { time }\end{array}$} & \multicolumn{8}{|c|}{ Number of activities performed over the last four weeks } \\
\hline & & Shopping & Cooking & $\begin{array}{l}\text { Cooking for } \\
\text { guest }\end{array}$ & Washing-up & Cleaning & Ironing & Do-it-yourself & Gardening \\
\hline \multicolumn{10}{|l|}{ Model A } \\
\hline Child: girl & $\begin{array}{l}54.461 * * * \\
(3.55)\end{array}$ & $\begin{array}{l}1.815^{*} \\
(1.71)\end{array}$ & $\begin{array}{l}9.641^{* *} \\
(2.11)\end{array}$ & $\begin{array}{l}3.991^{* * *} \\
(2.58)\end{array}$ & $\begin{array}{l}10.806^{* * *} \\
(3.68)\end{array}$ & $\begin{array}{l}7.512^{* * *} \\
(4.75)\end{array}$ & $\begin{array}{l}12.865^{* * *} \\
(7.34)\end{array}$ & $\begin{array}{l}-12.154^{* * *} \\
(-6.79)\end{array}$ & $\begin{array}{l}-4.243^{* * *} \\
(-2.59)\end{array}$ \\
\hline Child: age & $\begin{array}{l}4.259 * * * \\
(2.73)\end{array}$ & $\begin{array}{l}0.338^{* *} \\
(2.26)\end{array}$ & $\begin{array}{l}1.337^{* * *} \\
(6.03)\end{array}$ & $\begin{array}{l}0.458^{* *} \\
(2.41)\end{array}$ & $\begin{array}{l}1.394^{* * *} \\
(5.26)\end{array}$ & $\begin{array}{l}0.387^{* *} \\
(2.09)\end{array}$ & $\begin{array}{l}0.766^{* * * *} \\
(3.91)\end{array}$ & $\begin{array}{l}0.342 \\
(1.59)\end{array}$ & $\begin{array}{l}0.092 \\
(0.41)\end{array}$ \\
\hline Father: domestic time/activity & $\begin{array}{l}0.092^{* * *} \\
(2.61)\end{array}$ & $\begin{array}{l}0.037 \\
(0.51)\end{array}$ & $\begin{array}{l}0.087 \\
(1.04)\end{array}$ & $\begin{array}{l}0.319 \\
(1.27)\end{array}$ & $\begin{array}{l}0.315^{* * *} \\
(4.20)\end{array}$ & $\begin{array}{l}0.235^{* * *} \\
(2.96)\end{array}$ & $\begin{array}{l}0.714^{* *} \\
(2.34)\end{array}$ & $\begin{array}{l}0.219^{* * *} \\
(3.74)\end{array}$ & $\begin{array}{l}0.310^{* * *} \\
(4.13)\end{array}$ \\
\hline Mother: domestic time/activity & $\begin{array}{l}0.061^{*} \\
(1.67)\end{array}$ & $\begin{array}{l}0.086 \\
(1.63)\end{array}$ & $\begin{array}{l}-0.043 \\
(-0.38)\end{array}$ & $\begin{array}{l}0.100 \\
(0.85)\end{array}$ & $\begin{array}{l}0.141^{*} \\
(1.77)\end{array}$ & $\begin{array}{l}0.010 \\
(0.20)\end{array}$ & $\begin{array}{l}0.012 \\
(0.13)\end{array}$ & $\begin{array}{l}0.160 \\
(1.39)\end{array}$ & $\begin{array}{l}0.017 \\
(0.21)\end{array}$ \\
\hline Father: domestic time/activity * Child: girl & $\begin{array}{l}0.055 \\
(1.19)\end{array}$ & $\begin{array}{l}0.068 \\
(0.77)\end{array}$ & $\begin{array}{l}-0.072 \\
(-0.66)\end{array}$ & $\begin{array}{l}0.482 \\
(1.22)\end{array}$ & $\begin{array}{l}-0.254^{* * *} \\
(-2.59)\end{array}$ & $\begin{array}{l}-0.054 \\
(-0.46)\end{array}$ & $\begin{array}{l}-1.022^{*} \\
(-1.85)\end{array}$ & $\begin{array}{l}-0.270^{* *} \\
(-2.53)\end{array}$ & $\begin{array}{l}-0.263^{* *} \\
(-1.99)\end{array}$ \\
\hline Mother: domestic time/activity * Child: girl & $\begin{array}{l}0.014 \\
(0.31)\end{array}$ & $\begin{array}{l}0.089 \\
(1.23)\end{array}$ & $\begin{array}{l}0.016 \\
(0.11)\end{array}$ & $\begin{array}{l}0.267 \\
(1.61)\end{array}$ & $\begin{array}{l}0.110 \\
(1.08)\end{array}$ & $\begin{array}{l}0.139 * * \\
(2.18)\end{array}$ & $\begin{array}{l}0.072 \\
(0.58)\end{array}$ & $\begin{array}{l}0.161 \\
(0.94)\end{array}$ & $\begin{array}{l}0.396^{* * *} \\
(2.63)\end{array}$ \\
\hline Test: Father's time $=$ mother's time & {$[0.29 ; 0.591]$} & {$[0.30 ; 0.582]$} & {$[1.31 ; 0.252]$} & {$[0.63 ; 0.427]$} & {$[2.53 ; 0.112]$} & {$[5.06 ; 0.025]$} & {$[4.76 ; 0.029]$} & {$[0.18 ; 0.673]$} & {$[5.90 ; 0.015]$} \\
\hline Test: Father's time * girl $=$ mother's time * girl & {$[0.39 ; 0.532]$} & {$[0.03 ; 0.856]$} & {$[0.37 ; 0.545]$} & {$[0.24 ; 0.625]$} & {$[6.69 ; 0.010]$} & {$[2.01 ; 0.156]$} & {$[3.67 ; 0.055]$} & {$[4.06 ; 0.044]$} & {$[8.26 ; 0.004]$} \\
\hline $\begin{array}{l}\text { Log likelihood } \\
\text { Model B }\end{array}$ & -6096.5 & -3292.9 & -3090.4 & -601.2 & -3575.1 & -3640.9 & -1651.2 & -1688.9 & -922.3 \\
\hline Child: girl & $\begin{array}{l}62.995^{* *} \\
(2.33)\end{array}$ & $\begin{array}{l}1.098 \\
(0.49)\end{array}$ & $\begin{array}{l}10.127 \\
(1.52)\end{array}$ & $\begin{array}{l}4.489 \\
(1.18)\end{array}$ & $\begin{array}{l}1.110 \\
(0.18)\end{array}$ & $\begin{array}{l}1.320 \\
(0.38)\end{array}$ & $\begin{array}{l}2.033 \\
(0.34)\end{array}$ & $\begin{array}{l}-14.083^{* * *} \\
(-6.81)\end{array}$ & $\begin{array}{l}-8.754^{* * *} \\
(-3.19)\end{array}$ \\
\hline Child: age & $\begin{array}{l}4.245^{* * *} \\
(2.72)\end{array}$ & $\begin{array}{l}0.339^{* *} \\
(2.26)\end{array}$ & $\begin{array}{l}1.333^{* * *} \\
(6.01)\end{array}$ & $\begin{array}{l}0.457^{*} \\
(1.90)\end{array}$ & $\begin{array}{l}1.241^{* * *} \\
(4.61)\end{array}$ & $\begin{array}{l}0.388^{* *} \\
(2.08)\end{array}$ & $\begin{array}{l}0.755^{* * *} \\
(3.64)\end{array}$ & $\begin{array}{l}0.298 \\
(1.30)\end{array}$ & $\begin{array}{l}-0.223 \\
(-0.94)\end{array}$ \\
\hline Parents: domestic time/activity & $\begin{array}{l}0.071^{* * *} \\
(3.16)\end{array}$ & $\begin{array}{l}0.067 \\
(1.52)\end{array}$ & $\begin{array}{l}0.012 \\
(0.14)\end{array}$ & $\begin{array}{l}0.121 \\
(1.12)\end{array}$ & $\begin{array}{l}0.131^{*} \\
(1.66)\end{array}$ & $\begin{array}{l}0.051 \\
(1.23)\end{array}$ & $\begin{array}{l}0.036 \\
(0.35)\end{array}$ & $\begin{array}{l}0.183^{* * *} \\
(3.46)\end{array}$ & $\begin{array}{l}0.128^{* * *} \\
(2.60)\end{array}$ \\
\hline Share of mother's domestic time/activity & $\begin{array}{l}-9.976 \\
(-0.44)\end{array}$ & $\begin{array}{l}-1.513 \\
(-0.78)\end{array}$ & $\begin{array}{l}-3.044 \\
(-0.85)\end{array}$ & $\begin{array}{l}-1.286 \\
(-0.42)\end{array}$ & $\begin{array}{l}-8.037^{* *} \\
(-2.17)\end{array}$ & $\begin{array}{l}-8.796^{* * *} \\
(-3.31)\end{array}$ & $\begin{array}{l}-6.682 \\
(-1.43)\end{array}$ & $\begin{array}{l}-2.825 \\
(-1.39)\end{array}$ & $\begin{array}{l}-2.030 \\
(-1.31)\end{array}$ \\
\hline Parents: domestic time/activity * Child: girl & $\begin{array}{l}0.030 \\
(0.94)\end{array}$ & $\begin{array}{l}0.079 \\
(1.43)\end{array}$ & $\begin{array}{l}-0.045 \\
(-0.38)\end{array}$ & $\begin{array}{l}0.169 \\
(1.04)\end{array}$ & $\begin{array}{l}0.006 \\
(0.06)\end{array}$ & $\begin{array}{l}0.116^{* *} \\
(2.10)\end{array}$ & $\begin{array}{l}0.059 \\
(0.46)\end{array}$ & $\begin{array}{l}-0.154 \\
(-1.55)\end{array}$ & $\begin{array}{l}0.076 \\
(0.83)\end{array}$ \\
\hline $\begin{array}{l}\text { Share of mother's domestic time/activity * } \\
\text { Child: girl }\end{array}$ & $\begin{array}{l}-15.906 \\
(-0.60)\end{array}$ & $\begin{array}{l}1.019 \\
(0.42)\end{array}$ & $\begin{array}{l}1.303 \\
(0.30)\end{array}$ & $\begin{array}{l}1.356 \\
(0.37)\end{array}$ & $\begin{array}{l}12.895^{* * *} \\
(2.81)\end{array}$ & $\begin{array}{l}6.753^{*} \\
(1.93)\end{array}$ & $\begin{array}{l}10.865^{*} \\
(1.79)\end{array}$ & $\begin{array}{l}9.880^{* * *} \\
(2.72)\end{array}$ & $\begin{array}{l}7.055^{* *} \\
(2.23)\end{array}$ \\
\hline Log likelihood & -6073.5 & -3285.1 & -3088.9 & -421.3 & -3341.0 & -3581.3 & -1561.2 & -1452.5 & -740.7 \\
\hline
\end{tabular}

Source: INSEE Time Use survey 1999, authors' calculations.

Note: estimates from Tobit models. Standard errors are clustered at the family level, significance levels being respectively $1 \%(* * *), 5 \%(* *)$ and $10 \%(*)$. The total sample comprises 1,507 children (1,082 families), but observations with zero values for both paternal and maternal times are excluded in panel B. The other family characteristics include number of siblings, number of sisters, birth order, father's age, difference between father and mother's age, blended family, father's education (four categories), two dummies comparing father and mother's education (mother and father have same education, mother is more educated), father's employment, mother's full-time employment, mother's part-time employment, household income (log), number of rooms per household member, presence of dishwasher and of microwave oven, having a garden, living in a rural area and interviewed on either Saturday or Sunday. 
Table 6. Joint estimation of parental and child domestic activities

\begin{tabular}{|c|c|c|c|c|c|c|c|c|c|}
\hline \multirow[t]{2}{*}{ Variables } & \multirow{2}{*}{$\begin{array}{l}\text { Daily } \\
\text { domestic } \\
\text { time }\end{array}$} & \multicolumn{8}{|c|}{ Number of activities performed over the last four weeks } \\
\hline & & Shopping & Cooking & $\begin{array}{l}\text { Cooking for } \\
\text { guest }\end{array}$ & Washing-up & Cleaning & Ironing & Do-it-yourself & Gardening \\
\hline \multicolumn{10}{|l|}{ Model A - parent and child equations } \\
\hline$\%$ of censored values for parents & 0.6 & 0.2 & 0.3 & 41.9 & 10.3 & 2.1 & 6.3 & 20.4 & 43.1 \\
\hline Specification for parental equation & Continuous & Continuous & Continuous & Tobit & Tobit & Continuous & Tobit & Tobit & Tobit \\
\hline$\%$ of censored values for child & 38.6 & 50.0 & 57.7 & 92.7 & 52.0 & 45.9 & 77.6 & 77.6 & 88.7 \\
\hline Specification for child's equation & Tobit & Tobit & Tobit & Tobit & Tobit & Tobit & Tobit & Tobit & Tobit \\
\hline $\begin{array}{l}\text { Correlation between residuals of parental } \\
\text { and child equations }\end{array}$ & $\begin{array}{l}0.168^{* * *} \\
(6.08)\end{array}$ & $\begin{array}{l}0.129 * * * \\
(4.06)\end{array}$ & $\begin{array}{l}0.018 \\
(0.56)\end{array}$ & $\begin{array}{l}0.168^{* * *} \\
(4.25)\end{array}$ & $\begin{array}{l}0.169 * * * \\
(5.08)\end{array}$ & $\begin{array}{l}0.113 * * * \\
(4.05)\end{array}$ & $\begin{array}{l}0.050 \\
(1.19)\end{array}$ & $\begin{array}{l}0.164^{* * *} \\
(4.62)\end{array}$ & $\begin{array}{l}0.262^{* * *} \\
(6.36)\end{array}$ \\
\hline Log likelihood & -16250.5 & -9183.3 & -8478.0 & -3680.8 & -9474.2 & -9529.2 & -6738.4 & -6721.4 & -4829.7 \\
\hline \multicolumn{10}{|c|}{ Model B - father, mother and child equations } \\
\hline$\%$ of censored values for father & 27.3 & 35.4 & 61.4 & 87.1 & 58.5 & 69.5 & 93.6 & 25.2 & 55.6 \\
\hline Specification for father's equation & Tobit & Tobit & Tobit & Tobit & Tobit & Tobit & Tobit & Tobit & Tobit \\
\hline$\%$ of censored values for mother & 1.8 & 2.6 & 1.5 & 44.9 & 13.2 & 3.1 & 7.2 & 79.1 & 62.4 \\
\hline Specification for mother's equation & Continuous & Continuous & Continuous & Tobit & Tobit & Continuous & Tobit & Tobit & Tobit \\
\hline$\%$ of censored values for child & 38.6 & 50.0 & 57.7 & 92.7 & 52.0 & 45.9 & 77.6 & 77.6 & 88.7 \\
\hline Specification for child's equation & Tobit & Tobit & Tobit & Tobit & Tobit & Continuous & Tobit & Tobit & Tobit \\
\hline Correlation between residuals of father & $0.170 * * *$ & $0.073^{*}$ & $-0.247^{* * *}$ & $0.223^{* * *}$ & $0.103^{* * *}$ & -0.042 & -0.110 & $0.153^{* * *}$ & $0.281^{* * *}$ \\
\hline and mother equations & $(4.83)$ & (1.89) & $(-7.68)$ & (5.29) & (2.58) & $(-1.01)$ & $(-1.54)$ & (3.05) & (6.49) \\
\hline Correlation between residuals of father & $0.168^{* * *}$ & $0.086^{* *}$ & $0.062^{*}$ & $0.169 * *$ & $0.162^{* * *}$ & $0.138^{* * *}$ & 0.082 & $0.148 * * *$ & $0.237 * * *$ \\
\hline and child equations & $(5.35)$ & $(2.50)$ & $(1.68)$ & $(2.48)$ & $(4.45)$ & $(3.51)$ & $(1.13)$ & (3.99) & $(5.05)$ \\
\hline Correlation between residuals of mother & $0.104 * * *$ & $0.121 * * *$ & -0.020 & $0.151 * * *$ & $0.138 * * *$ & 0.039 & 0.043 & $0.146^{* * *}$ & $0.239 * * *$ \\
\hline and child equations & $(3.22)$ & $(3.85)$ & $(-0.67)$ & $(3.62)$ & $(3.97)$ & $(1.26)$ & $(1.02)$ & $(3.08)$ & $(4.77)$ \\
\hline Log likelihood & -23094.4 & -12757.7 & -10769.9 & -4399.4 & -12188.0 & -11163.7 & -7241.5 & -8006.4 & -6603.3 \\
\hline
\end{tabular}

Source: INSEE Time Use survey 1999, authors' calculations.

Note: estimates from conditional mixed process regressions. Standard errors are clustered at the family level, significance levels being respectively $1 \%(* * *), 5 \%(* *)$ and $10 \%(*)$. The total sample comprises 1,507 children (1,082 families). Each equation include the following family characteristics: number of siblings, number of sisters, birth order, father's age, difference between father and mother's age, blended family, father's education (four categories), two dummies comparing father and mother's education (mother and father have same education, mother is more educated), father's employment, mother's full-time employment, mother's part-time employment, household income (log), number of rooms per household member, presence of dishwasher and of microwave oven, having a garden, living in a rural area and interviewed on either Saturday or Sunday. 
Table 7. Random and fixed effect estimates of paternal and maternal domestic time on child's domestic time

\begin{tabular}{lllll}
\hline Variables & $(1)$ & $(2)$ & $(3)$ & $(4)$ \\
\hline Child: girl & $65.082^{* * *}$ & $60.922^{* * *}$ & $2.137^{* * *}$ & $153.920^{* * *}$ \\
& $(8.37)$ & $(4.13)$ & $(2.91)$ & $(3.73)$ \\
Child: age & $4.344^{* * *}$ & $4.329^{* * *}$ & 0.167 & 4.179 \\
& $(2.78)$ & $(2.77)$ & $(1.58)$ & $(0.55)$ \\
Father: domestic time & $0.116^{* * *}$ & $0.094^{* * *}$ & & \\
& $(4.74)$ & $(2.95)$ & & -0.032 \\
Mother: domestic time & $0.062^{* *}$ & $0.065^{*}$ & & $(-0.27)$ \\
& $(2.46)$ & $(1.95)$ & & $-0.224^{* *}$ \\
Father: domestic time * Child: girl & & 0.048 & 0.003 & $(-1.97)$ \\
& & $(1.10)$ & $(1.24)$ & YES \\
Mother: domestic time * Child: girl & & -0.006 & $-0.003^{*}$ & $(-1.72)$ \\
Other family characteristics & & $(-0.13)$ & YES & [3.93;0.140] \\
Test: Father's time = mother's time & {$[1.98 ; 0.159]$} & {$[0.33 ; 0.567]$} & & - \\
Test: Father's time ${ }^{*}$ girl = mother's time * girl & & {$[0.69 ; 0.405]$} & {$[3.96 ; 0.137]$} \\
Log likelihood & -6082.5 & -6081.9 & -96.1 & \\
\hline
\end{tabular}

Source: INSEE Time Use survey 1999, authors' calculations.

Note: (1) and (2) are estimates from random effect Tobit models, (3) are estimates from a fixed-effect conditional Logit model and (4) are estimates from a fixed effect Tobit model. Significance levels are respectively $1 \%\left({ }^{* * *}\right), 5 \%\left({ }^{* *}\right)$ and $10 \%$ $\left({ }^{*}\right)$. The sample comprises 1,507 children (1,082 families). The fixed effect Logit model is estimated on 322 observations (348 families). The other family characteristics include number of siblings, number of sisters, birth order, father's age, difference between father and mother's age, blended family, father's education (four categories), two dummies comparing father and mother's education (mother and father have same education, mother is more educated), father's employment, mother's full-time employment, mother's part-time employment, household income (log), number of rooms per household member, presence of dishwasher and of microwave oven, having a garden, living in a rural area and interviewed on either Saturday or Sunday. 